\title{
THE STRATIGRAPHY OF THE UPPER CRETACEOUS ROCKS NORTH OF THE ARKANSAS RIVER IN EASTERN COLORADO
}

\author{
By C. H. Dane, W. G. Pierce, and J. B. Reeside, Jr.
}

\begin{abstract}
A comparison of the stratigraphic sections of the rocks of Benton age in western Kansas and the southern foothill region of eastern Colorado indicates the probability that the lower nembers of the Greenhorn of Kansas merge westward into the nnper part of the Graneros shale of the foothills, the Green-

rn of the type locality being much thinner than that of western Kansas and the Graneros of the type locality being much thicker than the Graneros of western Kansas. The Greenhorn of Prowers County, Colo., north of the Arkansas River, has, however, the thickness of the Kansas Greenhorn, and the member subdivisions of the Greenhorn made in Kansas can also be recognized in Prowers County. The Carlile shale, which overlies the Greenhorn, contains at the top the persistent but variable Codell sandstone member. This member, which contains the Carlile fauna, is believed to have been deposited in shallow water under conditions that were maintained for a considerable period of time. The faunal discontinuity between the Carlile and the overlying Niobrara formation is believed to represent a time lapse, although no evidence was seen to indicate subaerial erosion of the Carlile.

In the foothill region of Colorado the Niobrara consists of the Timpas limestone member and the overlying Apishapa shale member. The Timpas includes in its upper part limy shales and thin limestone beds which, in Kansas, have been excluded from the basal Hays limestone member. The Hays limestone member appears to be a more satisfactory lithologic and faunal unit, and the name is therefore extended into that part of Colorado east of the foothills and north of the Arkansas River. Similarly, the name "Smoky Hill" is extended from the chalk member of that name in Kansas to the marl member overlying the Hays limestone in eastern Colorado.

The basal portion of the overlying Pierre shale consists of black shale nearly devoid of fossils, to which the name "Sharon Springs member" is extended from the type locality in Wallace County, Kans. The overlying portion of the Pierre shale was not sufficiently studied to warrant the establishment of member names, although the "rusty zone", "tepee zone", and "transition zone" of previous authors are recognized.

The known invertebrate faunas of the several formations are briefly described, and the fauna of the overlying Fox Hills sandstone is also discussed because of its close relationship to the fauna of the "transition zone" of the Pierre shale.
\end{abstract}

\section{INTRODUCTION}

During parts of the summers of 1931 and 1932 C. H. Dane and W. G. Pierce spent about 8 months on a reconnaissance examination of a large area of the High Plains of eastern Colorado north of the Arkansas River. A few additional observations on the lower part of the Upper Cretaceous section in the southern foothills re- gion were made by C. H. Dane in the fall of 1933 . The invertebrate faunas collected during this reconnaissance have been studied by J. B. Reeside, Jr., who has also contributed many hitherto unpublished data. Although detailed work has been done in several areas in this region, no summary of the stratigraphy has been published for many years, and it has therefore seemed appropriate to publish the data gathered in the present study and to correlate them with the previous work. Because of the large size of the area traversed, it was not possible to make a rigorous examination of any specific problem, though considerable information was obtained concerning the lower portion of the Upper Cretaceous.

The location of the area within which most of the observations here recorded were made is shown on the index map (fig. 9), which also shows the location of some areas covered by previous reports.

The geologic map (pl. 64) shows the areas of outcrop of the principal stratigraphic divisions with reference to the major geographic and cultural features of the region. The base was taken from the United States Geological Survey map of Colorado compiled in 1922, with minor modifications of land lines, drainage, and culture observed by the writers in the field or suggested by more recently compiled maps. The mapping was done wholly by sketching, either on county maps or on so-called military maps of the Colorado State Highway Commission, which show towns, railroads, and graded roads with considerable accuracy.

The formations exposed are of Upper Cretaceous and Tertiary age. The Cretaceous rocks were laid down in the widespread seas that covered much of the western interior of the United States at that time. During the period in which the earlier deposits accumulated there was some differential warping of the crust, but subsidence later became more pronounced in an area centering somewhat north of Denver. During the epoch of subsidence a basin was formed which filled with sediments as it subsided, the later Cretaceous rocks thus having a much greater thickness toward the central part of the basin. Toward the end of the Cretaceous and early in the Tertiary the rising Rocky Mountains shed great quantities of debris eastward to form a series of nonmarine deposits. Although the 
seas had withdrawn, the basin continued to subside until deposition ceased, probably in early Eocene time. The latest structural movements accompanying the rise of the Rocky Mountains completed the outline of the sedimentary basin and made it a structural basin as well. There ensued a period in which erosion was predominant, and the main outlines of the present areal geology of the Cretaceous rocks were formed by the beveling of the inclined strata. Somewhat later, in middle and late Tertiary time, gravelly debris was

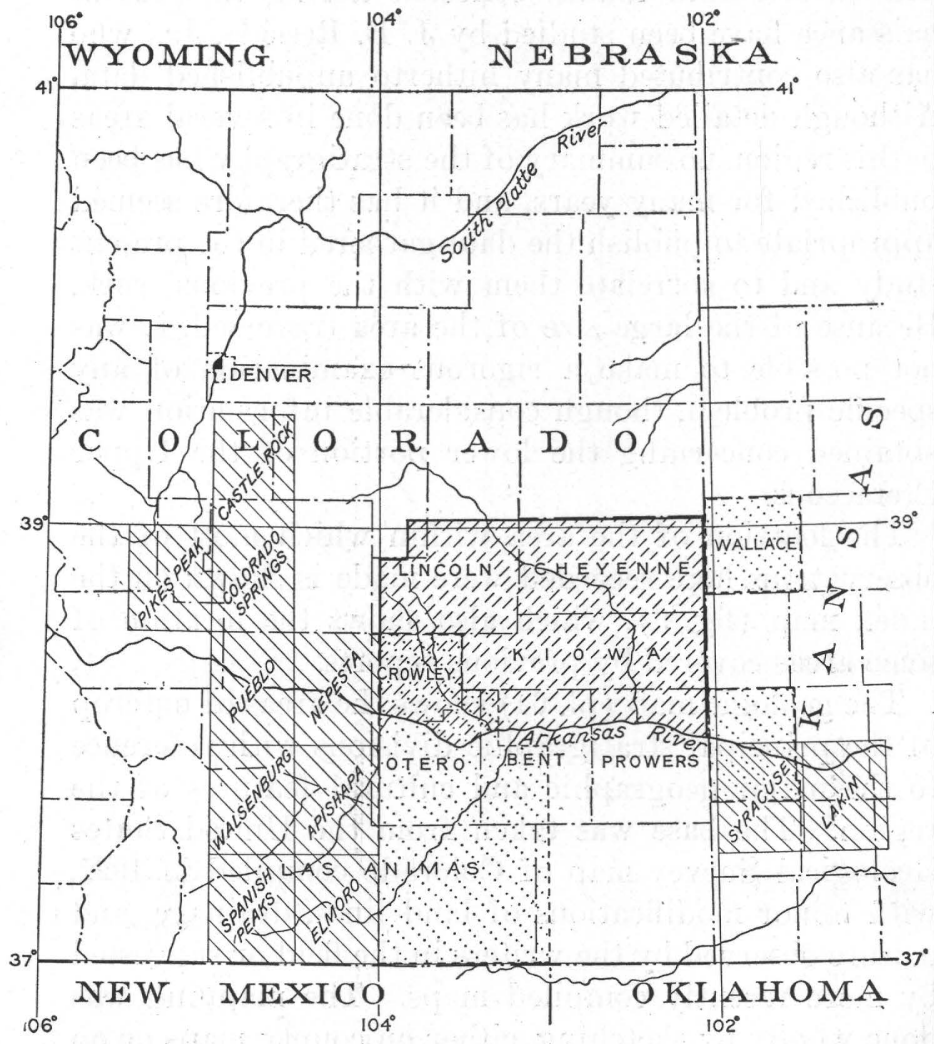

Figure 9.-Index map showing location of area in eastern Colorado considered in this report (shown by short-dashed lines) and of some areas described in previous reports, including folios of the Geologic Atlas of the United States (cross-lined) and reports of the Colorado and Kansas Geological Surveys (dotted).

swept out from the mountains by streams, and widespread though comparatively thin deposits of gravel and sand were laid down. The great plain thus built up sloped gently eastward, its materials concealing the underlying Cretaceous rocks far east of the mountain front. Renewed erosion in still later epochs has cut away much of this plain and exposed the underlying rocks, but large areas of it still remain, and beneath these areas the Cretaceous rocks are wholly concealed. Even where the present surface has been cut below the level of the High Plains deposits, there are extensive areas where the Cretaceous rocks are concealed by relatively late terrace deposits at several levels, surface wash, and sand dunes, and the alluvial deposits of the larger streams. For the greater part also the Creta- ceous rocks are soft and easily erodible, and even where not concealed by younger deposits they may be weathered into smooth ungullied sod-covered slopes in which the details of the lithology cannot be determined. No attempt has been made to indicate on the map the distribution of terraces, wash, or eolian deposits, which in places conceal the Tertiary as well as the Cretaceous rocks. The extent of the present alluvial plain of the Arkansas River is shown only approximately.

\section{EARLIER WORK}

The first comprehensive studies of the Cretaceous stratigraphy of the Arkansas Valley were begun by G. K. Gilbert in 1893 with the mapping of the Pueblo quadrangle. ${ }^{1}$ Mapping of the Apishapa quadrangle ${ }^{2}$ was begun in the following year, and a subsequent reconnaissance of the more easterly portion of the valley led to the publication in 1896 of Gilbert's report on the underground water of the Arkansas Valley in eastern Colorado. ${ }^{3}$ The description of the Denver Basin, ${ }^{4}$ a more northerly area of the foothills and adjoining plains, was published at about the same time, though based on field work of the preceding decade. In the succeeding years several other folios ${ }^{5}$ were issued that followed closely the outlines of the stratigraphy laid down by Gilbert and that dealt with areas of the southern foothills and adjoining plains. In 1906 Darton's broader study ${ }^{6}$ of the geology and underground water of the Arkansas Valley was published. With the appearance of the Castle Rock folio ${ }^{7}$ in 1915 and the Colorado Springs folio ${ }^{8}$ in 1916 the earlier phase of the geologic study of the region came to an end, and most of the larger features of the geology had been outlined. Several detailed reports on areas-in the Arkansas Valley in Colorado have since appeared, and some features of the stratigraphic relations have been touched upon in other papers. In recent years several detailed studies have been made of the Upper Cretaceous rocks in western Kansas. ${ }^{9}$ In these studies finer division of the Cretaceous beds has been made than in

1 Gilbert, G. K., U. S. Geol. Survey Geol. Atlas, Pueblo folio (no. 36), 1897.

2 Stose, G. W., U. S. Geol. Survey Geol. Atlas, Apishapa folio (no. 186), 1912.

${ }^{3}$ Gilbert, G. K., U. S. Geol. Survey 17th Ann. Rept., pt. 2, pp. 351-601, 1896.

${ }^{4}$ Emmons, S. F., Cross, Whitman, and Eldridge, G. H., Geology of the Denver Basin in Colorado: U. S. Geol. Survey Mon. 27, 1896.

5 U. S. Geol. Survey Geol. Atlas, Elmoro folio (no. 58), 1899 Walsenberg folio (no. 68), 1900; Spanish Peaks folio (no. 71), 1901; Nepesta folio (no. 135), 1906.

${ }^{6}$ Darton, N. H., Geology and underground waters of the Arkansas Valley in eastern Colorado: U. S. Geol. Survey Prof. Paper 52, 1906. 7 U. S. Geol. Survey Geol. Atlas, Castle Rock folio (no. 198), 1915.

8 U. S. Geol. Survey Geol. Atlas, Colorado Springs folio (no. 203), 1916.

${ }^{\circ}$ Bass, N. W., Geologic investigations in western Kansas, pt. 2, Geology of Hamilton County : Kansas Geol. Survey Bull. 11, 1926. Elias, M. K., The geology of Wallace County, Kans.: Kansas Geol. Survey Bull. 18, 1931. 
the rocks of equivalent age in eastern Colorado. Although the observations recorded in this paper were made in reconnaissance, they show that some of the smaller units set up in Kansas can be recognized also in eastern Colorado. Much of the area offers small promise of results to be obtained from detailed work, but in places exposures are sufficient to justify more careful stratigraphic study than has yet been carried out.

\section{THE FORMATIONS}

In the area shown on plate 64 the Upper Cretaceous rocks include the formations from the Dakota sandstone to the lower part of the Pierre shale. West and north of the mapped area the higher part of the Pierre shale is present, overlain by the Fox Hills sandstone, the Laramie formation, and the Dawson arkose. The uppermost beds of the Pierre shale and higher Cretaceous rocks are not discussed at length in this paper, but certain observations, particularly the record of fossil collections, are given.

The stratigraphic divisions of the Upper Cretaceous rocks described in this paper are as follows:

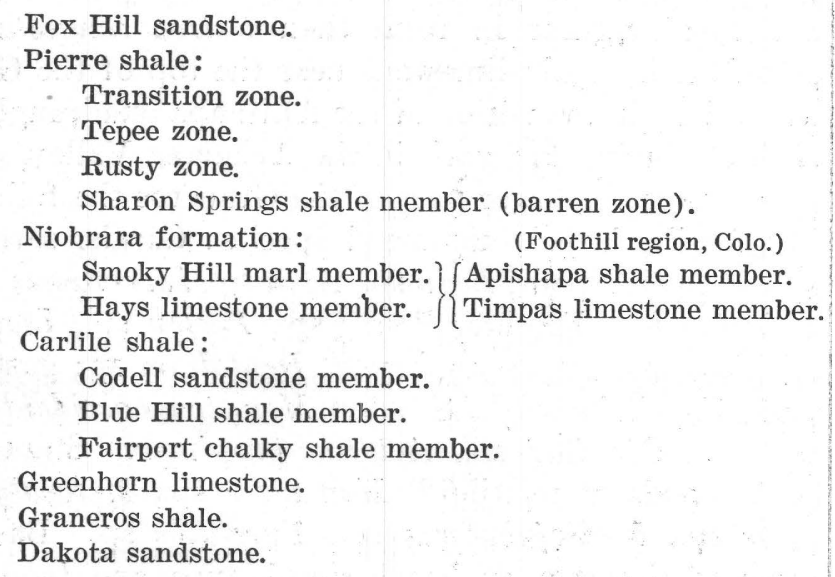

\section{DAKOTA SANDSTONE}

The Dakota sandstone, which is the basal formation of the Upper Cretaceous series of this region, crops out in a narrow strip adjacent to the alluvial plain along the north side of the Arkansas River and extends from the northwestern part of T. 23 S., R. 51 W., to the southwestern part of T. 22 S., R, 47 W. Only the upper part of the formation is exposed. In the exposures observed by the writers it consists principally of buff and white, uniformly fine-grained, cross-bedded sandstone, with weathered surfaces pitted. As much as 40 feet of sandstone of this type is exposed at one locality, but elsewhere the exposed thickness is much less. The total thickness is somewhat variable but probably does not exceed 100 feet. $^{10}$ Where a more nearly complete

\footnotetext{
10 Duce, J. T., Geology of parts of Las Animas, Otero, and Bent Counties; Colorado Geol. Survey Bull. 27, pt. 3, pp. 89-90, 1924.
}

section is exposed south of the Arkansas River it is described as a hard massive or quartzitic sandstone. ${ }^{11}$ Carbonaceous and lignitic layers and fossil leaves of Upper Cretaceous age are found locally in the sandstone.

\section{GRANEROS SHALE}

Exposures of the next overlying formation, the Graneros shale, occur in a narrow belt north of the Arkansas River and extending from a point south of Fort Lyon on the east to a point south of Wiley on the west, and also east of Holly in a small area near the Kansas-Colorado State line.

The Graneros shale was defined by Gilbert ${ }^{12}$ as a laminated argillaceous shale from 200 to 210 feet thick, the lowest formation of the Benton group. It was named from a creek in the northern part of the Walsenburg quadrangle.

The formation consists predominantly of dark-gray to black fissile noncalcareous shale. Because it is soft and easily erodible and because of the widespread deposition of terrace sands along the Arkansas River, exposures are so small and scattered that little information on the details of lithology, thickness, and stratigraphic relations can be obtained in this area.

The basal part of the Graneros is exposed at various places from sec. 4, T. 23 S., R. 51 W., eastward to the southwestern part of T. 22 S., R. 49 W. The basal Graneros in this area consists of well-bedded nonsandy shale, with thin bentonite beds at places. Although the basal contact was everywhere concealed, there seems to be an abrupt change in lithology from the cross-bedded sandstone of the underlying Dakota sandstone. In other areas there is a transition zone of sandy shale at the base of the Graneros. In Hamilton County, Kans., the basal 8 or 10 feet of the formation contains lenses of impure sandstone and sandy shale and layers of iron concretions 2 to 8 inches in diameter. ${ }^{13}$ South of the Arkansas River, in the La Junta area ${ }^{14}$ several feet of alternating shales and sandstones at the top of the Dakota form a transition to the overlying Graneros, and similar transitional relations have been observed in the vicinity of Pueblo ${ }^{15}$ and of Colorado Springs. ${ }^{16}$

\footnotetext{
11 Darton, N. H., Geology and underground waters of the Arkansas Valley in eastern Colorado: U. S. Geol. Survey Prof. Paper 52, pp. 25-27, 1906.

12 Gilbert, G. K., The underground water of the Arkansas Valley in eastern Colorado: U. S. Geol. Survey 17th Ann. Rept., pt. 2, pp. 564, $570,1896$.

${ }^{13}$ Bass, N. W., Geologic investigations in western Kansas, pt. 2, Geology of Hamilton County: Kansas Geol. Survey Bull. 11, p. 72, 1926.

${ }^{14}$ Patton, H. B., Underground water possibilities for stock and domestic purposes in the La Junta area, Colo.: Colorado Geol. Survey Bull. 27, pt. 1, p. 14, 1924.

15 Gilbert, G. K., U. S. Geol. Survey Geol. Atlas, Pueblo folio (no. $36)$, p. 3, 1897.

16 Finlay, G. I., U. S. Geol. Survey Geol. Atlas, Colorado Springs folio (no. 203), p. 8, 1916.
} 
In Hamilton County, Kans., ${ }^{17}$ the Graneros shale is from 60 to 65 feet thick. It is believed to have about the same thickness in the extreme eastern portion of the Arkansas Valley in Colorado, where, in addition, the same divisions of the overlying Greenhorn limestone may be recognized as in Hamilton County. In the northeastern part of Bent County, Colo., however, the Graneros shale is estimated by the writers to be about 200 feet thick, and although the overlying Greenhorn limestone is there incompletely exposed, it seems to be much thinner than in western Kansas. This relation suggests that the Graneros has thickened westward at the expense of the Greenhorn. In the western part of Bent County and in Otero County ${ }^{18}$ the Graneros has a thickness of about 200 feet, and farther west ${ }^{19}$ it is from 200 to 220 feet thick. In a section measured by the writers at Colorado City, west of Colorado Springs, the Graneros shale is 210 feet thick.

Lithologic subdivisions of the Graneros were not distinguishable in the small scattered exposures observed within the area covered by this report. In the region of La Junta and farther west in the Arkansas Valley ${ }^{20}$ the middle portion of the Graneros includes nearly black shales which contrast with somewhat lighter colored shales above and below. The subdivision into a nearly black middle portion and lighter-colored upper and lower portions is also recorded farther south in the vicinity of Walsenburg and Trinidad. ${ }^{21}$ The thickness. in those localities is given as 200 to 210 feet. This is also absut the thickness of the Graneros exposed at a locality about 10 miles northwest of Vermejo Park, on the east flank of the Sangre de Cristo Range, in New Mexico near its northern boundary. A calcareous concretionary zone occurs at 30 to 40 feet above the base, and a thin calcareous sandstone or sandy limestone oscurs 45 to 50 feet below the top. In the Apishapa quadrangle ${ }^{22}$ a bed of impure, sparingly fossiliferous lime tone 12 to 14 inches thick lies from 65 to 75 feet above the base, and a 6 -inch bed of hard sandstone occurs a few feet above the limestone. At 80 feet above the base of a section of Graneros measured by the writers at Colorado City, west of Colorado Springs, there is a prominent thin-bedded sandstone 1 foot thick with 2 feet 6 inches of gray sandy shale below it. Over the western part of the area described in this report and a considerable region to the west and south the Graneros

\footnotetext{
${ }^{17}$ Bass; N. W., op. cit., p. 72.

18 Patton, H. B., op. cit., p. 14.

19 Gilbert, G. K., op. cit. (Pueblo folio), p. 3. Fisher, C. A., U. S. Geol. Survey Geol. Atlas, Nepesta folio (no. 135), p. 2, 1906.

${ }^{20}$ Patton, H. B., op. cit., p. 14 . Gilbert, G. K., op. cit. (Pueblo folio), p. 3. Fisher, C. A., op. cit., p. 2 . Stose, G. W., U. S. Geol. Survey Geol. Atlas, Apishapa folio (no. 186), p. 5, 1912.

21 U. S. Geol. Survey Geol. Atlas, Walseriburg folio (no. 68), p. 1, 1900 ; Elmoro folio (no. 58), p. 1, 1899.

${ }^{22}$ Stose, G. W., op. cit., p. 5.
}

seems to maintain a fairly uniform thickness, and it is likely that a few individual beds in it may be recognized and traced over large areas.

Bentonite beds from a fraction of an inch to a few inches thick occur at several horizons within the Graneros. Although they afford a potentially useful means of detailed correlation, the inadequacy of exposures over much of the portion of eastern Colorado here discussed makes it unlikely that such detailed correlation can be effected without very careful recording of the formation where it is penetrated by wells. Southwest of Las Animas a bed of bentonite 3 feet thick $^{23}$ occurs about 85 feet above the base of the Graneros and has been recorded as "talc" in several wells drilled for water in the La Junta region. No beds of equal thickness are known elsewhere in this region. Beds of similar thickness have, however, been recorded in the lower part of the Benton ${ }^{24}$ shale of northeastern Colorado, which is the equivalent of the Graneros shale and the overlying Greenhorn and Carlile formations of the Arkansas Valley.

The fauna of the Graneros shale is scanty and imperfectly known. A small simple oyster somewhat larger and more regular in form than Ostrea congesta is abundant in sandy limestone near the top of the Graneros shale in the region of the Apishapa quadrangle. ${ }^{25}$ Gilbert, during his work in the Arkansas Valley, collected from the lower part of the Graneros the following fossils, largely unnamed species: Corals, several species; pelecypods, Leda sp., Arca sp., Inoceramus aff. I. bellvuensis Reeside, Pteria sp., Pecten sp., Lucina sp., Dosinopsis sp.; scaphopod, Dentalium sp; gastropods, Turritella whitei Stanton, Mesostoma occidentalis Stanton, Cinulia? sp., Actaeon propinquus Stanton; cephalopods, a nautiloid, Mammites sp., Metacalycoceras sp., Borissjakoceras sp., Turrilites sp. Bass ${ }^{26}$ :eported Ostrea n. sp., small simple type, and Inoceramus, n. sp. related to $I$. fragitis Hall and Meek from western Kansas.

A section of the Benton shale was measured by the writers along the south fork of Bear Creek 1.3 miles south of the place where the main road from Mount Morrison to Denver crosses the Dakota sandstone hogback. About 10 feet above the top of the Dakota sandstone and thus in beds equivalent to the Graneros shale the writers collected Holcolepis pulchellus Cockerell and Leucichthyops vagans Cockerell, species originally described from the Mowry shale. Several other small lots of fossils were collected at horizons 250 to 300 feet

${ }^{23}$ Patton, H. B., op. cit., pp. 14-15.

${ }_{24}$ Mather, K. F., Gilluly, James, and Lusk, R. G., Geology and oil and gas prospects of northeastern Colorado: U. S. Geol. Survey Bull. 796 , pp. $81-83,1928$.

25 Stose, G. W., op. cit., p. 6.

${ }^{26}$ Bass, N. W., op. cit., p. 73. 
above the base of the Benton in this section. These lots include the species in the following list:

Globigerina sp.

Globotruncana sp.

Inoceramus sp.

Ostrea sp.

Ptychodus sp.

\section{GREENHORN LIMESTONE}

The Greenhorn limestone was differentiated as a formation by Gilbert. ${ }^{27}$ It was so named from Greenhorn station, 14 miles south of Pueblo, and Greenhorn Creek. The formation as described by Gilbert is from 25 to 40 feet thick and consists of alternating beds of fine-grained, compact, pale bluish-gray limestone and light-gray laminated calcareous shale. The Greenhorn as recognized in western Kansas, however, has a thickness of 100 to 130 feet and includes three recognizable members in some places and four in others. It seems desirable to compare the exposures of the formation along the north side of the Arkansas Valley in Colorado with the thicker and divisible section of western Kansas.

In Hamilton County, Kans., which adjoins Colorado, Bass ${ }^{2 S}$ recognized three members of the Greenhornthe Bridge Creek limestone member at the top, the intermediate Hartland shale member, and the basal Lincoln limestone member. The Bridge Creek member consists of an alternation of limy shale and chalky limestone having a thickness of 74 feet, four-fifths of which consists of shale. It merges into the overlying Carlile shale with no apparent lithologic change but is separable from the Carlile faunally. Below the Bridge Creek member is a unit of calcareous shale, the Hartland shale member. This is 23 feet thick and almost devoid of limestone but contains, like the Bridge Creek member, many layers of bentonitic clay. The Lincoln limestone member, although consisting predominantly of calcareous shale, contains numerous thin beds of hard finely banded gray limestone that weathers brown. These beds are most abundant near the top and base of the member, which is 35 feet thick.

These divisions of the Greenhorn may also be recognized north of the Arkansas River in eastern Prowers County, Colo. The Bridge Creek member is exposed along the west side of Cheyenne Creek from the NW1/4 sec. 8, T. 23 S., R. 41 W., northward to the NE $1 / 4$ sec. 6 of the same township. A partial and approximate section follows:

27 Gilbert, G. K., The underground water of the Arkansas Valley in eastern Colorado: U. S. Geol. Survey 17th Ann. Rept., pt. 2, pp. $564-565,570,1896$.

${ }^{28}$ Bass, N. W., op. cit., pp. 66-70.
Partial section of Bridge Creek member of Greenhorn limestone on west side of Cheyenne Creek in Prowers County, Colo.

Limestone, gray; weathers into hard yellowish-gray irregular flat slabs; numerous Inoceramus labiatus

Concealed

Limestone, gray, with Inoceramus labiatus

Concealed____... 2

Limestone, gray, with Inoceramus labiatus__________- 26

Concealed____. 36

Limestone, gray

Concealed

Limestone, gray

Concealed

Limestone, gray

Concealed__._.

Limestone, gray, with Inoceramus labiatus______._._. 8

Concealed___- 16

Limestone, gray, with Inoceramus labiatus__._._._._._. 8

Concealed______-____-_._- 2

Limestone, gray, with Inoceramus labiatus___._._._._. 8

Concealed____ 56

(Above this point the section is approximate.)

Limestone, gray, bedded____._. 6

Shale, chalky, poorly exposed

Limestone, chalky, thin-bedded______._. 5

Shale, chalky, poorly exposed_______ 1

Limestone, white, chalky

Shale, chalky, thin-bedded, with a few hard white and gray limestone lenses less than half an inch thick_._-- 211

Bentonite

Limestone, gray; weathers white; single bed, with vertical joints from 2 to 8 inches apart; upper part somewhat chalky

Shale, chalky, paper-bedded ____ 110

Limestone, gray; weathers white; single bed, with vertical joints from 2 to 8 inches apart

Shale, chalky, well bedded, with a few layers of gray crystalline limestone one-sixteenth inch thick _._._._. 1

Limestone, gray; weathers white; in lenses as much as 2 inches thick and 6 inches long

Shale, chalky, well bedded, with one zone of limestone lenses 2 inches thick below the water level of a dug pool.

Total measured

This section when plotted can be correlated at least approximately with the lower part of the section of the Bridge Creek member published by Bass. $^{29}$ The 5 -inch bentonite bed resting on 6 inches of limestone can be correlated with a similar bed near the base of the Hamilton County section, and a zone of abundant fossils 30 to 40 feet higher appears in both sections. Many of the intermediate limestone beds also seem to match. Unfortunately the exposures along Cheyenne Creek were not sufficiently good to permit the recognition of other bentonite beds. However, near the southeast corner of the SW1/4 sec. 12 , T. 23 S., R. 41 W., a bed of bentonite $51 / 2$ inches thick crops out above a bed of limestone 6 inches thick and below chalky shale. This

${ }^{29}$ Idem, fig. 21. 
may well be the bed measured in the section west of Cheyenne Creek, given above.

In the $\mathrm{SE} 1 / 4$ sec. $12, \mathrm{~T} .23 \mathrm{~S} .$, R. $42 \mathrm{~W}$., somewhat more than 40 feet of soft chalky shale is exposed. These beds contain scattered limestone lenses as much as 2 inches thick but no continuous beds of limestone. They represent the Hartland shale member. Below them in the NE1/4 sec. 18 and NW1/4 sec. 17, T. $23 \mathrm{~S}$., R. $41 \mathrm{~W}$., the basal part of the Greenhorn is exposed above the Graneros shales. The beds include chiefly calcareous shales, but also hard crystalline limestone beds as much as 2 inches thick, which weather into hard yellowish and brownish plates. The limestone beds constitute only about 10 percent of the exposed rocks but because of their resistance to erosion are conspicuous on the outcrop. These lowest exposures of the Greenhorn correspond in lithology and probably also in thickness with the Lincoln limestone member as recognized in western Kansas.

In the SW1/4 sec. 11, T. 23 S., R. 42 W., exposures of the uppermost part of the Greenhorn limestone include beds of gray limestone and chalky marl. Part of the limestone, however, occurs as flat but rounded lenses or concretionary lenses from 6 to 12 inches thick.

The upper part of the Greenhorn limestone is also exposed in the NW1/4 sec. 18 and the W1/2 sec. 7, T. $22 \mathrm{~S}$., R. $44 \mathrm{~W}$. It consists of alternating beds of chalky marl and gray limestone, and the limestone beds have a thickness of 6 to 12 inches and carry numerous specimens of Inoceramus labiatus. There are also some lenses of hard gray crystalline limestone largely composed of fossil shells. In somewhat lower Greenhorn exposures in this vicinity there are less numerous impressions of Inoceramus labiatus and other fossils, and the limestones are less platy in habit, breaking rather into irregular chunks. Exposures of the lower part of the Greenhorn that might include possible equivalents of the Hartland shale member and Lincoln limestone member were not observed. In the northcentral part of sec. 7, T. 22 S., R. 44 W., a partial section of the top of the Greenhorn limestone and basal part of the overlying Fairport chalky shale member of the Carlile shale was measured, as follows:

Partial section of top of Greenhorn limestone and base of Carlile shale in see. 7, T. 22 S., $R .44 \mathrm{~W}$.

Fairport chalky shale member of Carlile shale:

Chalky shale.

Limestone, gray, with Inoceramus

Chalky shale

Limestone, gray.

Chalky shale

Limestone, white, hard; breaks in curving plate and flat slabs; in part weathering to yellowish gray
Partial section of top of Greenhorn limestone and base of Carlile shale in sec. 7, T. 22 S., R. 44 W.-Continued

Fairport chalky shale member of Carlile shale-Contd. Chalky shale, white, thin-bedded. Ft. in

Chalk, white; breaks into thin chips 3

Partial thickness 4

Greenhorn limestone:

Limestone, light gray, dense, in part weathering to yellowish gray, less fossiliferous than lower beds; breaks along vertical joints into flat and irregular vertical plates

Chalky marl, gray, in part thin-bedded gray limestone; numerous Inoceramus and oyster shell fragments

Limestone, gray.

Chalky marl, poorly exposed.

Limestone, gray, dense; breaks into numerous irregular flat slabby plates and chips; in part stained rusty yellow; Inoceramus labiatus.

Chalky marl, soft, poorly exposed

Limestone, gray; breaks into thin flat chips in lower 2 inches; Inoceramus labiatus

Chalky marl, in part flaky and paper-bedded_____-_ 1

Limestone, gray; weathers very light gray; dense, with an irregular lower surface. Contains abundant Inoceramus labiatus

Chalky marl, flaky and paper-bedded in part_-_.--_ 1

Limestone, chalky, gray; breaks into irregular flat chips

Chalky marl, yellowish gray, flaky and paper-bedded in part.

Partial thickness

Total measured $11 \quad 11$ 2011

No precise correlation can be made of this partial section with the partial section measured along Cheyenne Creek. The lower part may include some beds equivalent to the upper part of the Cheyenne Creek section, or it may include only beds higher than the top of the section measured on Cheyenne Creek.

The thickness and lithology of the Greenhorn in the region north of Lamar are very imperfectly known, but there is some suggestion that a thickness comparable with that farther east may be present and that the underlying Graneros has also a small thickness like that of western Kansas.

Somewhat farther west, $11 / 2$ miles north of McClave, a section was measured of the upper part of the Greenhorn, possibly including some of the lowest part of the Fairport chalky shale member of the Carlile shale:

Section of upper part of Greenhorn limestone $1 \frac{1}{2}$ miles north of McClave

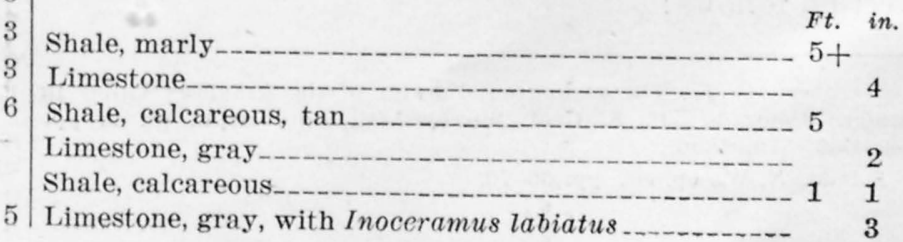




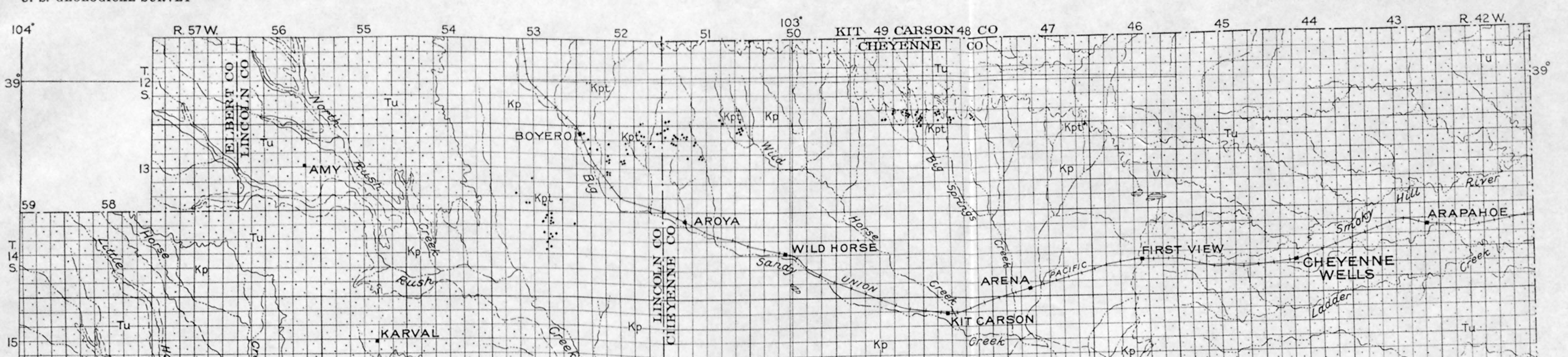

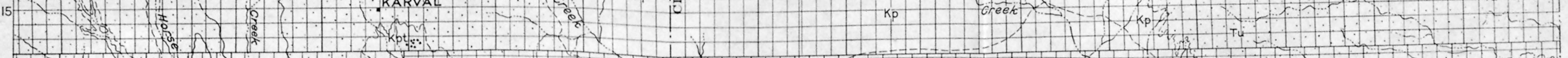

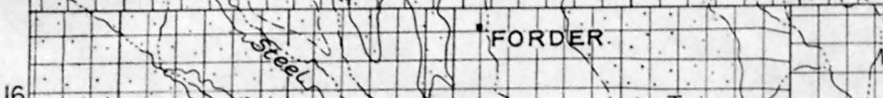

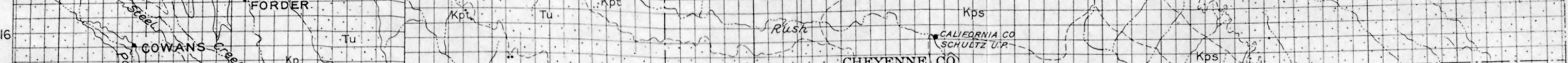

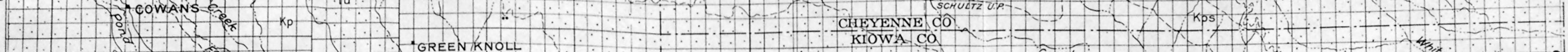

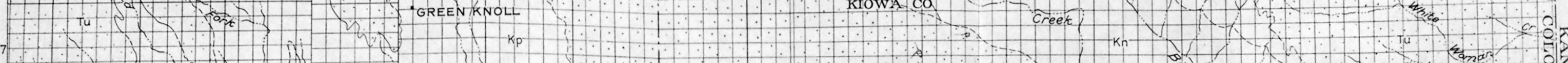

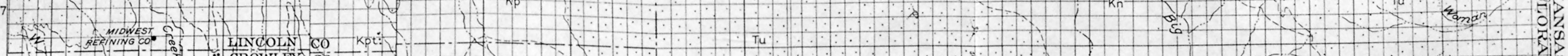

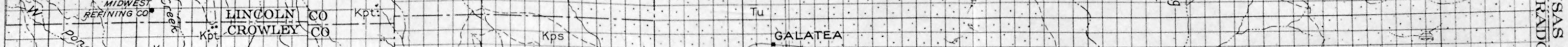

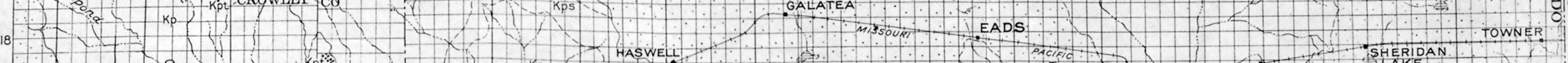

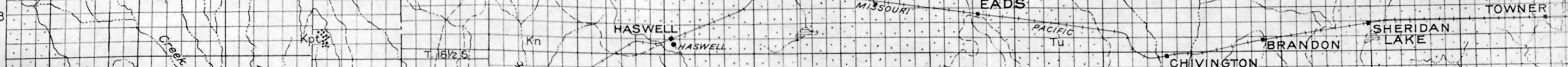

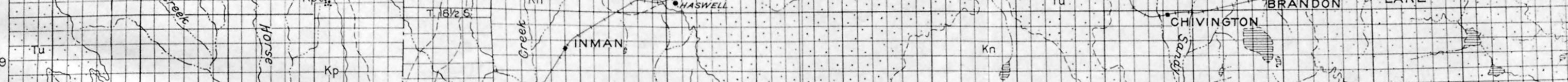

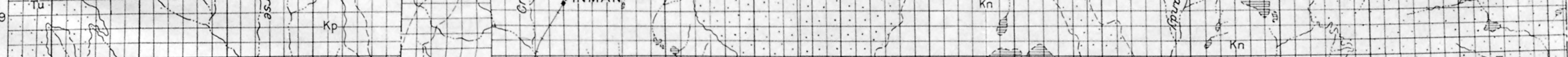

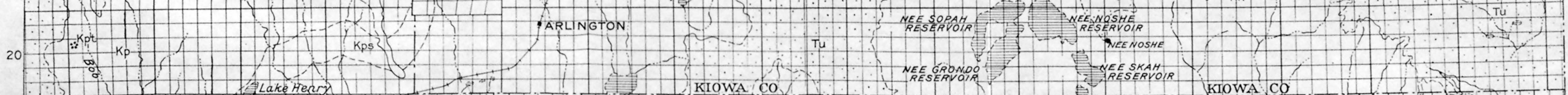

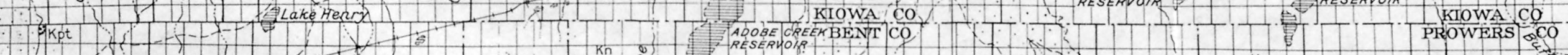

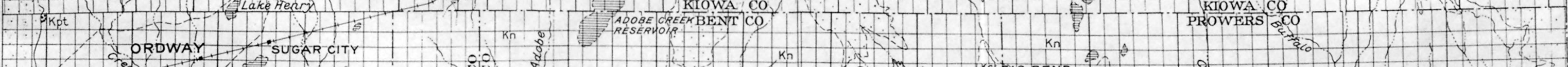

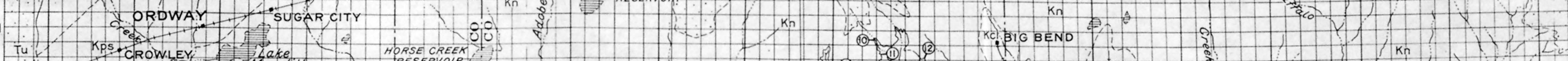

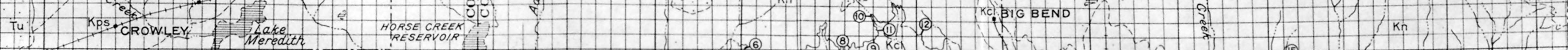

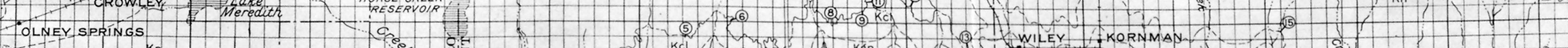

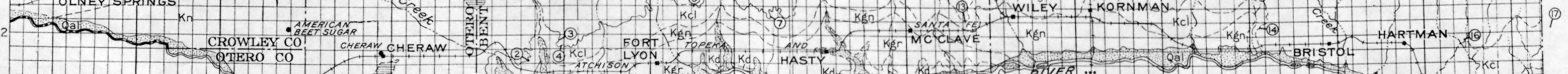

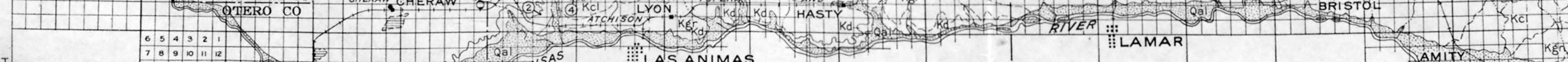
$\mathrm{T}$
23
$\mathrm{~S}$

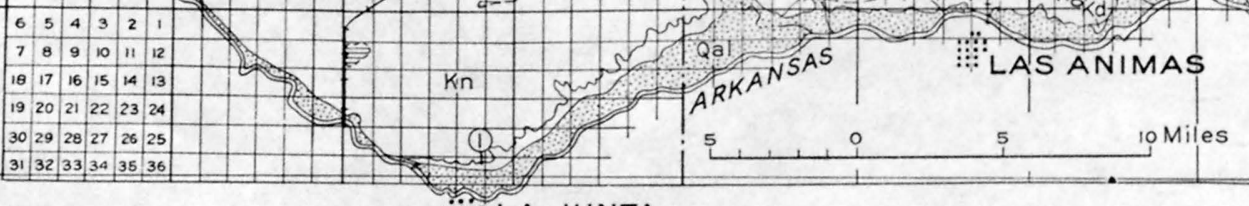

I:- LA JUNTA

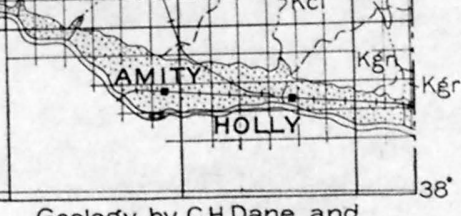

GEOLOGIC MAP OF PART OF EASTERN COLORADO NORTH OF THE ARKANSAS RIVER 
Section of upper part of Greenhorn limestone $1 \frac{112}{2}$ miles north of McClave-Continued

Chalky marl, tan, with shell fragments

Ft. in.

Limestone, gray 3

Marl, tan

Limestone, light blue gray, with Inoceramus labiatus

Marl and shale.

3

Limestone, marl

2

Shale and marl

Limestone, light gray

Shale, calcareous

Limestone, light gray

Marl

Limestone, blue gray, with Inoceramus labiatus

Marl, tan

Limestone

Marl, tan

Limestone, blue gray, hard

Marl, with a small amount of limestone

Marl and shale, buff

Limestone, gray

Marl

Limestone, granular, soft

Marl, shaly, tan, with Inoceramus labiatus

Limestone, white to light gray

Marl, with a small amount of limestone

Limestone, gray, with Inoceramus labiatus

Marl, tan

Limestone, white

Marl, $\tan$

Limestone, blue gray

Marl

Limestone

Marl, tan

Limestone, light gray

Marl_

Limestone, blue gray, hard

Marl, tan and light gray

Limestone, blue gray.

Marl, tan and dirty brown

Limestone, light gray, vertically jointed

Marl, tan

Limestone, white

Marl, $\tan$

Bentonite

Shale, chalky

Limestone, white

Shale, chalky tan

Limestone, white

Shale, chalky tan

Limestone, white

Marly chalk

Total measured

Total measured

Small exposures of the upper part of the Greenhorn limestone in the $\mathrm{SW} 1 / 4$ sec. 16, T. 22 S., R. 50 W., along the western part of the south line of sec. 8, T. $22 \mathrm{~S}$., R. 50 W., in the SE1/4 sec. 11, T. 22 S., R. 51 W., and in the northern part of sec. 35, T. 22 S., R. 53 W., show that it persists westward as a lithologic unit of alternating limestone and chalky shale beds, but its thickness is not known, and exposures of the lower part were not observed.

$77388-37-2$
In the NW $1 / 4 \mathrm{NW}^{1} / 4$ sec. 5, T. 24 S., R. 54 W., south of the Arkansas River, exposures of Greenhorn limestone about 30 feet thick show that it consists of beds of white limestone from 4 to 8 inches thick interbedded with gray calcareous shale in beds 6 to 12 inches thick. Inoceramus labiatus is present in abundance at these exposures.

In the Pueblo quadrangle ${ }^{30}$ the Greenhorn has a thickness of 35 to 50 feet. East of that area, in the Nepesta quadrangle, ${ }^{31}$ it has an aggregate thickness of 50 feet, and to the south, in the Apishapa quadrangle, ${ }^{32}$ it is reported to be about 30 feet thick. In the Walsenburg quadrangle it is described as consisting of layers, from 3 to 4 inches thick, of dove-colored limestone, separated by partings of gray shale. The aggregate thickness is about 30 feet. At a locality 10 miles northwest of Vermejo Park, on the east flank of the Sangre de Cristo Range, in New Mexico near its northern boundary, the Greenhorn, as separated by the writers; includes 25 feet of such alternating limestones and shales and also 25 feet of hard gray limy shale overlying them. The Greenhorn may also be recognized farther west in southwestern Colorado and on the east side of the San Juan Basin in northwestern New Mexico as a similar thin unit of alternating beds of limestone and shale. In the La Junta region ${ }^{33}$ the total thickness is about 50 or 60 feet. In view of the fact that the thickness of the Greenhorn in western Kansas is from 100 to 130 feet, it seems likely that the lower members of the Greenhorn in Kansas merge westward into the upper part of the Graneros shale. This inference is supported by the westward thickening of the Graneros shale.

The thickness of the rocks of Benton age in the aggregate remains nearly the same from west to east, as shown by the plotted logs of several wells (fig. 10) and also by the thicknesses given for the several formations by writers on various areas (to defer, for the present, consideration of an anomalously thin Carlile shale section in the La Junta region). The published descriptions of the upper portion of the Graneros where it has a thickness of 200 feet also suggest that its content of calcareous shale and limestone is greater than that of the Graneros of western Kansas and that it may represent an equivalent of the lower portion of the Greenhorn of Kansas. For example, in the La Junta region ${ }^{34}$ the Graneros contains thin limy beds 40 to 50 feet below the top of the formation, and in the Apishapa quadrangle ${ }^{35}$ a thin fossiliferous platy sand-

${ }^{30}$ Gilbert, G. K., U. S. Geol. Survey Geol. Atlas, Pueblo folio (no. $36)$, p. 3, 1897.

sisher, C. A., op. cit., p. 2.

32 Stose, G. W., op. cit., p. 6.

33. Patton, H. B., op. cit., p. 15.

${ }^{34}$ Idem, pp. 14-15.

${ }^{35}$ Stose, G. W., op. cit., p. 5 . 
stone is found about 45 feet below the top of the Graneros. Farther west, however, in a section measured by the writers at Colorado City, west of Colorado Springs, the upper portion of the Graneros contains no limy beds. In this section the Graneros is 210 feet thick and the Greenhorn somewhat more than 20 feet. The width of outcrop of the Greenhorn as shown on the geologic map diminishes rather abruptly westward from the vicinity of Wiley.

So far as known the Greenhorn in Colorado is transitional into the overlying Carlile shale as well as into the underlying Graneros shale. A paleontologic distinction between Carlile and Greenhorn is reported in western Kansas and may exist also in eastern Colorado.

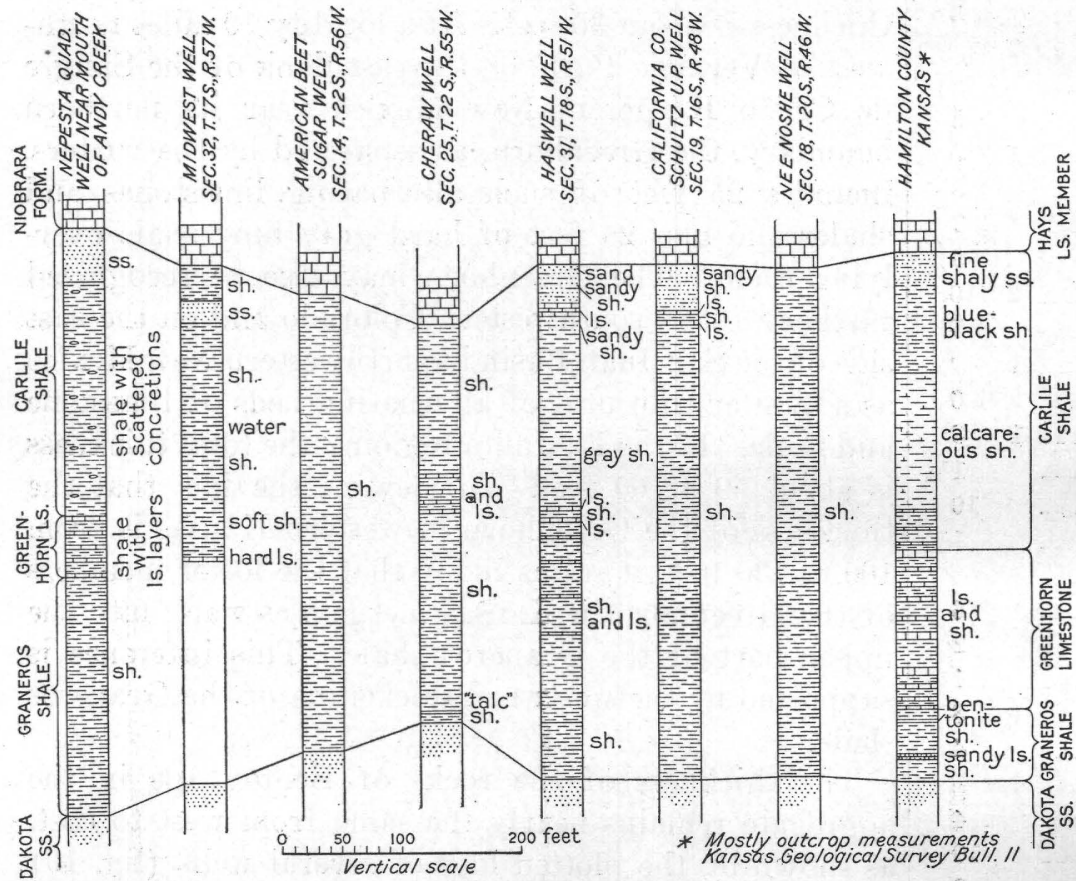

Figure 10.-Graphic sections showing the thickness of the rocks of Benton age at various places in the Arkansas. Valley as given by drillers' logs of several wells, with a comparison of the stratigraphic section of these rocks as divided in Hamilton County, Kans., and in the Nepesta quadrangle, Colo.

The fossils recorded from the Graneros of eastern Colorado are of types also found in the Greenhorn and may therefore have come from shaly beds equivalent to the lower part of the Greenhorn.

Fossils other than a few species of Foraminifera and Inoceramus labiatus are not common in the Greenhorn limestone. Seven collections made by the writers contain the following species. The large numbers (15743, ete.) in this and other lists of localities are the numbers in the United States Geological Survey Mesozoic invertebrate collection.

Locality

Globigerina sp.

$1,2,3,6$

Globotruncana sp

Inoceramus labiatus Schlotheim

Inoceramus sp
Lunatia? sp

Exiteloceras pariense (White)

1. 15743, Mount Morrison-Bear Creek locality. (See p. 210.)

2. 15818 , secs. 16 and 17, T. 22 S., R. 50 W.

3. $16068, \mathrm{NW}^{1 / 4}$ sec. 18 , T. 22 S., R. 44 W., along Cottonwood Creek.

4. $16069, \mathrm{SW}^{1} / 4$ sec. 7 , T. 22 S., R. 44 W.

5. $16076, \mathrm{NE}_{1} / 4$ sec. 11 , T. 22 S., R. $48 \mathrm{~W}$.

6. $16077, \mathrm{NW}^{1 / 4}$ sec. 30 , T. 22 S., R. $46 \mathrm{~W}$.

7. $16078, \mathrm{NE}^{1} / 4$ sec. 12 , T. 22 S., R. $49 \mathrm{~W}$.

The rarer species, however, include a considerable variety of forms. Reeside has under study collections from the Greenhorn limestone of the Arkansas Valley and the foothill region of Colorado that contain the following forms in addition to those listed above: Echinoid, Sternotaxis? n. sp.; brachiopod, Ċrania n. sp.; pelecypods, Inoceramus cf. I. lamarcki Parkinson, Ostrea sp., Sauvagesia? sp.; gastropods, Cerithium? sp., Anchura? sp., Aporrhais (Perissoptera) prolabiata White, Anisomyon? sp.; cephalopods, Neoptychoceras sp., Baculites gracilis Shumard, Tragodesmoceras n. sp., Watinoceras? coloradoense (Henderson), Watinoceras? n. sp., Romaniceras n. sp., Neocardioceras septemseriatus (Cragin), Thomasites n. sp., Mammites n. sp., Neoptychitês n. sp., Scaphites n. sp., Pseudotissotia (Choffaticeras) n. sp., Metoicoceras whitei Hyatt, Metoicoceras cf. $M$. irwini Moreman. Morrow ${ }^{36}$ records Tragodesmoceras bassi Morrow from Colorado.

\section{CARLILE SHALE}

The Carlile shale was named by Gilbert ${ }^{37}$ from Carlile Spring and Carlile station, 21 miles west of Pueblo. It was described as a gray argillaceous shale 175 to 200 feet thick. In the Pueblo quadrangle the upper fourth contains some sand, and the topmost portion is described as a yellow friable sandstone. Farther east "the sandstone is often replaced by a purplish limestone." Large septarian calcareous concretions occurring 20 to 50 feet below the top of the formation are also noted.

In Russell County, Kans., the Carlile shale was divided into two members, the Blue Hill shale member above and the Fairport chalky shale member ${ }^{38}$ below. These subdivisions were later recognized in Ellis and

${ }^{30}$ Morrow, A. L., Cephalopods from the Upper Cretaceous of Kansas : Jour. Paleontology, vol. 9, no. 6, p. 468 , pl. 53, fig. 4 ; text fig. 1,1935 ,

${ }^{37}$ Gilbert, G. K., The underground water of the Arkansas Valley in eastern Colorado: U. S. Geol. Survey 17th Ann. Rept., pt. 2, pp. $565-566,570,1896$.

${ }^{38}$ Rubey, W. W., and Bass, N. W., The geology of Russell County, Kans. : Kansas Geol. Survey Bull. 10, p. 33, 1925. 
Hamilton Counties. ${ }^{39}$ In Ellis County a fine-grained sandstone about 20 feet thick at the top of the Carlile shale was named the Codell sandstone bed of the Blue Hill member by Bass. The Codell sandstone bed was also found in Hamilton County, Kans., near the Colorado State line, where it consists of sandstone about 2 feet thick in the upper part, underlain by 20 feet of sandy shale. The subdivisions of the Carlile shale made in Kansas are distinguishable also in the Arkansas Valley in eastern Colorado. As it is now generally regarded as desirable to eliminate the application of names to units of less than member rank, the Codell sandstone as herein described is considered to be a member of the Carlile shale, equivalent in rank to the Blue Hill shale member, which underlies it, and to the Fairport chalky shale, which is the basal member of the Carlile shale in the area of this report. The Codell sandstone has previously been recognized as a member of the Benton shale in northeastern Colorado. ${ }^{40}$

\section{FAIRPORT CHALKY SHALE MEMBER}

In Hamilton County, Kans., the Fairport chalkyshale member consists of calcareous blue-black shale in the upper part, which becomes more limy and somewhat lighter in color downward. Thin beds of chalky limestone alternate with limy shales in the basal 35 feet. The member as a whole has a thickness of nearly 150 feet. The contact with the overlying Blue Hill was not sharply distinguished. At the base the Fairport lithologically resembles the upper part of the Greenhorn limestone, but is paleontologically distinguishable from it.

At most places in the area shown on the map this lowest member. of the Carlile is poorly exposed in comparison with the two overlying members. There are some typical exposures of the upper part of the Fairport in the $\mathrm{NW}^{1} / 4$ sec. 28, T. 22 S., R. $41 \mathrm{~W}$. The exposures consist of yellowish well-bedded chalky shale with rather numerous specimens of Ostrea sp., Inoceramus sp., fragmentary remains of fish, and rarer ammonites.

The best exposures of the Fairport member are in the SE1/4 sec. 6 and the NE1/4 sec. 7, T. 22 S., R. 44 W. At the base it is much like the upper part of the underlying Greenhorn, as shown in the measured section on page 212 , but has possibly a somewhat more chalky aspect. The proportion of limestone diminishes rapidly upward, and the bulk of the exposures consists of chalky shale. In the $\mathrm{SW} 1 / 4 \mathrm{SE} 1 / 4$ sec. 6 a hard thinbedded oyster-shell limestone near the top of the Fairport makes a small ledge. There are, however, some

${ }^{39}$ Bass, N. W., Geologic investigations in western Kansas, pt. 1, Geology of Ellis County: Kansas Geol. Survey Bull. 11, p. 26, 1926 ; pt. 2, Geology of Hamilton County: Idem, p. 63.

${ }^{40}$ Mather, K. F., Gilluly, James, and Lusk, R. G., op. cit. (Bull. 796). p. 81 chalky marls above it, and the contact with the overlying Blue Hill shale member is not sharply distinguishable.

Small exposures in the northeastern part of T. 22 S., R. 48 W., show that much of the Fairport there consists of chalky marl with lenses of hard gray crystalline limestone a fraction of an inch thick. Oyster shells are abundant, as are also impressions of Inoceramus shells. Beds of limestone as much as 1 foot thick are locally present.

The contact between the Fairport and the overlying Blue Hill in sec. 27 and the NE1/4 sec. 34, T. 21 S., R. 49 W., cannot be precisely set, but near the top of the Fairport is a bed 1 to 6 inches thick of very fine grained sandy crystalline limestone or calcareous sandstone. This bed is really an aggregate of lenticular beds 1 inch or less thick. Some of the lenses consist of closely packed oyster shells, and many of them carry broken Inoceramus fragments, worn shark teeth, and oyster shells. Below the bed lie slightly calcareous wellbedded shales and marly shales. There is apparently considerable variation in the lime content of individual beds, which range from one-sixteenth to one-half inch thick. The proportion of calcareous or marly shales increases downward, and the lamination of the rock becomes less regular and less distinct. The lowest exposures consist of light-gray chalky marl, with numerous fish scales, oysters, and Inoceramus impressions. At least 25 feet of the upper part of the Fairport is exposed.

Somewhat more than 20 feet of chalky marl of the Fairport is also exposed in the SW1/4 sec. 9 and the NE $1 / 4$ sec. 16, T. 22 S., R. 50 W. The basal part of the overlying Blue Hill member is concealed.

The Fairport chalky shale member is 147 feet thick in Hamilton County, Kans., ${ }^{41}$ as determined from the $\log$ of a water well. No complete measurements of the member were made in eastern Colorado, but the member is estimated to be from 75 to 125 feet thick.

In the La Junta region and farther west in the Nepesta and Pueblo quadrangles ${ }^{42}$ the Fairport chalky shale member cannot be recognized from the descriptions of the Carlile shale given in the literature. In a section of the Carlile measured by the writers at Colorado City, west of Colorado Springs, 55 feet of gray limy shale underlies black noncalcareous shale and overlies gray limestone assigned to the Greenhorn limestone.

\section{BLUE HILL SHALE MEMBER}

The Blue Hill shale member consists predominantly of black fissile noncalcareous shale. In the lower part

\footnotetext{
41 Bass, N. W., op. cit., p. 65.

${ }^{42}$ Patton, H. B., op. cit., pp. 42-43. Fisher, C. A., op. cit., p. 2. Gilbert, G. K., U. S. Geol. Survey Geol. Atlas, Pueblo folio (no. 36), p. $3,1897$.
} 


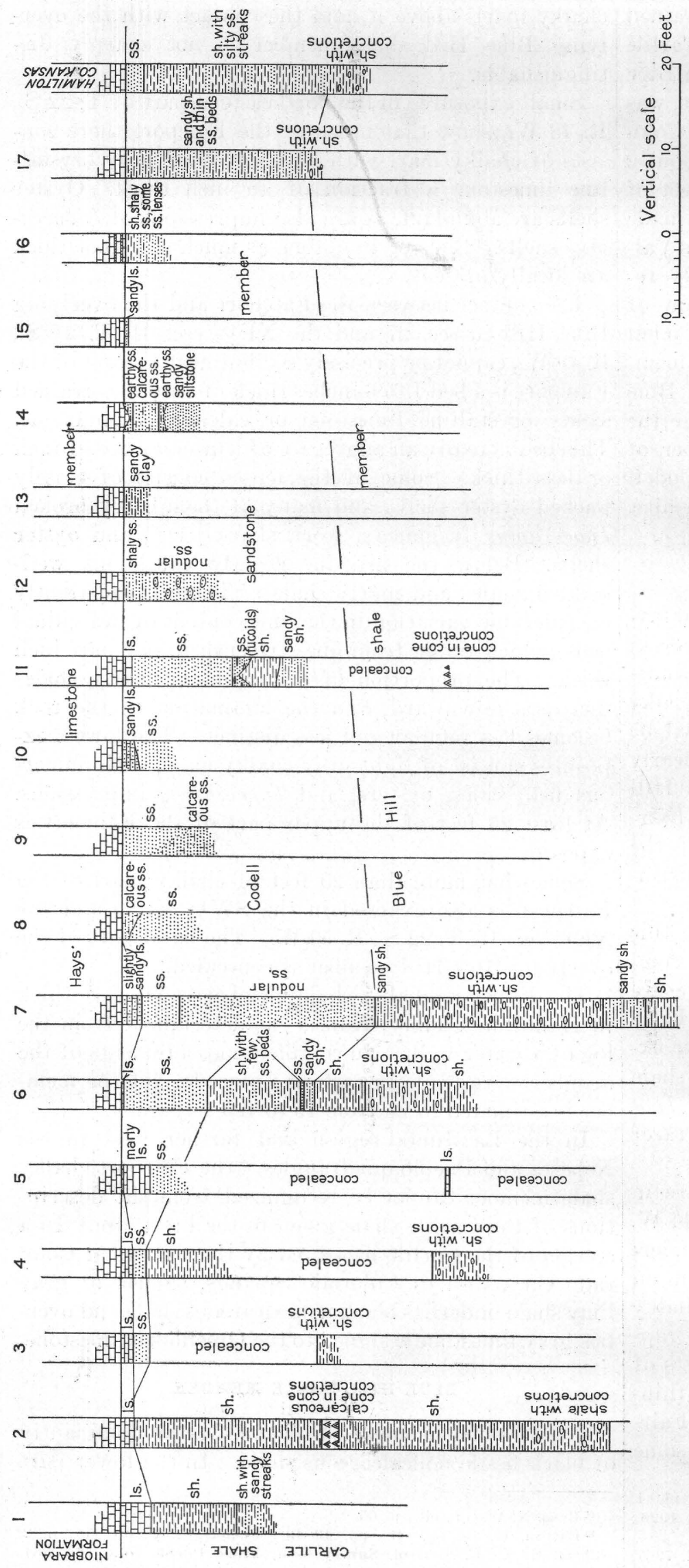

there is some calcareous shale, and the unit is not sharply separable from the underlying Fairport. The uppermost part consists of slightly sandy shale, locally as much as 30 feet thick. In the upper part of the member there are almost everywhere large calcareous septarian concretions. These are commonly several feet in diameter and may be as much as 10 feet. The material of which they are composed is a dull bluish-gray dense argillaceous limestone, but they weather yellowish tan. They are abundantly seamed with septaria of calcite in coarse translucent tan crystals. Conein-cone structure is developed on many of the upper surfaces. These large septarian concretions may occur through a zone from 5 to 30 feet in thickness, in most places about 10 feet. The stratigraphic position of the zone, however, seems to vary somewhat, for they may occur from 20 to 55 feet below the top of the Carlile shale. (See fig. 11.) Concretions of the same nature and at the same stratigraphic position in the Carlile shale have been described as far west as the Pueblo quadrangle ${ }^{43}$ and also to the east in Kansas. ${ }^{44}$

\section{CODELL SANDSTONE MEMBER}

At the top of the Carlile shale is a persistent but rather variable unit consisting of sandstone and sandy shale. This is the Codell sandstone member. Where originally described in Ellis County, Kans., ${ }^{45}$ it consists chiefly of sandstone with some shaly sandstones interbedded. At the base it grades into the shale beds of the Blue Hill member. The Codell becomes less sandy southward, and in Hamilton County, Kans., it is made up of about 20 feet of gritty shale containing thin streaks of shaly sandstone, overlain by 2 feet of sand at the top.

At the easternmost locality observed by the writers (locality 17, pl. 64), along Cheyenne Creek in Kansas, a third of a mile southeast of the northeast corner of sec. 17, T. 22 S., R. 41 W. (Colorado), the Codell consists of 22 feet of soft, nodular-weathering sandy shale. Near the

\footnotetext{
43 Gilbert, G. K., op. cit., p. 3

${ }^{44}$ Bass, N. W., op. cit., p. 63.

${ }^{45}$ Idem, p. 28.
} 
center of sec. 21, T. 22 S., R. 42 W. (locality 16, pl. 64), good exposures of the upper part of the Codell in a creek bank show that it consists of regularly bedded gray shale and lighter-colored, fine-grained shaly sand, with a few lenses of yellowish-gray hard sandstone.

Near the center of sec. 18, T. 22 S., R. 44 W. (locality 14, pl. 64), the upper part of the Codell is exposed in the wall of the Amity Canal ditch. At this place it has a somewhat different aspect. (See fig. 11.) At the top is a bed of soft earthy sand from 6 to 12 inches thick. Below this is a hard calcareous sandstone or sandy limestone 3 feet thick, of a rusty-brown color. Irregular bedding is outlined by sheets and lenses of softer earthy sandstone, which is cross-bedded within lenses. Fucoids interlace through the rock in great numbers. It also contains the typically prismatic fragments of Inoceramus shells. Below this hard bed is 6 to 12 inches of soft earthy sand, which is underlain by soft gray sandy siltstone. In sec. 6, T. 22 S., R. $44 \mathrm{~W}$., the top bed of the Codell is a hard brown, slightly sandy limestone. It is underlain by soft sandy siltstone. Good exposures of the Codell were not observed for about 20 miles west of this locality.

In a deep gully along the east side of the section-line road between secs. 10 and 11, T. 22 S., R. 48 W. (locality 13, pl. 64), however, the Codell consists of gray sandy clay mottled irregularly with white and lightgray sand, and no hard beds were observed in it. At several localities in the southwestern part of T. 21 S., R. $49 \mathrm{~W}$., one or more beds of hard dark brownishgray calcareous sandstone are present in the Codell. Such beds were observed as much as 12 feet below the top and also near or at the top. Characteristically they contain fish scales, fucoids, Halymenites major, and other fossil impressions. The mass of the Codell is soft crumbly silty sandstone, poorly bedded, and for the most part having a nodular or lumpy surface in vertical though somewhat weathered exposures.

West of locality 8 (pl. 64 and fig. 11) there is a hard gray bituminous limestone at all exposures observed. This limestone ranges from a few inches to several feet in thickness and is believed to be the bed which has been widely termed "Niobenton." Weathering to a rusty-brown color and having a rough granular fracture, it has the appearance of a calcareous sandstone, but in reality it contains only a small percentage of sand. It is characteristically interlaced with fucoids and carries numerous other fossils, including shark teeth. Even where thin it is notably persistent. It is much more resistant to erosion than the underlying beds and forms a definite escarpment. The thickness of the soft sandy shale and earthy sand of the Codell diminishes rapidly westward from about 30 feet in
T. 22 S., R. 50 W., to less than 5 feet in the western part of T. 22 S., R. 51 W. (See fig. 11.) In the south-central part of T. 22 S., R. 53 W., and thence southwestward there is no appreciable sand or sandy shale below the hard gray limestone. The limestone is, however, recognized to the west, in the La Junta region. ${ }^{46}$

A petrographic examination of several specimens of the hard bed at the top of the Carlile shows that in most places it is a limestone that contains 3 percent or less of sand, but in some places it contains about 60 percent of sand. In the SE1/4 sec. 21 , T. $21 \mathrm{~S}$., R. $49 \mathrm{~W}$., there are lenses of bituminous limestone in a bed as much as 6 inches thick of shale and sandstone cemented with lime, which overlies a hard sandstone bed that is as much as 18 inches thick. (See pl. 65,D.) The upper bed contains less than 2 percent of sand and the lower bed about 60 percent. The minerals in either the predominantly limestone or predominantly sandstone beds, after the $\mathrm{CaCO}_{3}$ has been removed, are found to be practically the same and in roughly the same proportions. This is also true of the Codell sand. These minerals and their approximate proportions, as determined by M. N. Bramlette, of the United States Geological Survey, are as follows:

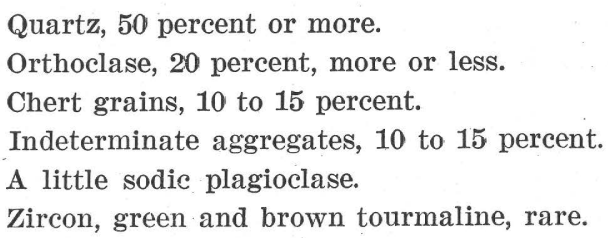

The writers regard the hard limestone (so-called "Niobenton") at the top of the Carlile in the westernmost part of the area as forming part of the Codell sandstone-in fact, as being the sole representative of the Codell in that area. Similar limestones occur within or at the top of the more typical Codell farther east, having the same abundance of fucoids, shark teeth, fish fragments, and imprints and casts of the same types of invertebrate fossils. As has been shown, these limestones contain a small percentage of sand, which in its more general aspects of composition and grain size at least is like that of the more sandy phases of the Codell. Moreover, limestone of this type is not present in either the underlying Blue Hill or the overlying Niobrara formation. As there is good reason to believe that the nondeposition of sand at this horizon in the La Junta region and perhaps somewhat farther west is a local phenomenon, it seems better to regard the contemporaneous limestone at the same horizon as a phase of the Codell.

${ }^{46}$ Patton, H. B., op. cit., pp. 17-18. 
About 5 miles west of Pueblo, on the north side of the Arkansas River, the following section of the top of the Carlile was measured by the writers:

Section of Carlile shate 5 miles west of Pueblo

Niobrara formation.

Carlile shale:

Shale, gray

Sandstone, light gray, hard, massive; weathers brown; Halymenites major and many fucoids, particularly near the base. Makes a vertical ledge, but the top few feet weathers back to a slope. 15

Shale, gray, and sandstone, thin-bedded, cross-bedded, with large ripple marks. This unit is separated by prominent shale partings above and below but is highly variable in lithology from place to place-_-_-

Sandstone, earthy; weathers dark gray to almost white, with the most part a yellowish tinge; weathers into irregular small nodular masses and has a "knotted" appearance on vertical or steep exposures; merges downward into sandy shale_

Shale, sandy

Shale, gray.

Total measured

At Colorado City, west of Colorado Springs, the top bed of the Carlile is a light-gray, thin-bedded, shaly sandstone from a fraction of an inch to 10 inches thick, containing vast numbers of Inoceramus. Below it is 9 feet 4 inches of hard brown calcareous sandstone with many fish teeth and scales, Ostrea sp., Inoceramus, probably I. fragitis, Scaphites warreni Meek and Hayden, and Prionocyclus wyomingensis Meek. This sandstone is ripple-marked, and the ripples have a wave length of 2 to 5 inches. Farther north, at Perry Park, in the NW1/4 sec. 24 , T. 9 S., R. $68 \mathrm{~W}$., a similar hard limy sandstone about 4 feet thick was observed.

Sandstone has been found at the top of the Carlile in many wells in northeastern Colorado; ${ }^{47}$ and the Codell sandstone, 3 to 20 feet or more thick, has also been recognized on the outcrop in the northern foothill region. ${ }^{48}$ It has been recorded also in most of the wells drilled within the area of the map. Its absence in a driller's log (see fig. 10) does not necessarily mean that the member is not present, as it may not have been noticed or recorded.

The top of the Carlile shale at the type locality ${ }^{49}$ is a yellow friable sandstone, which corresponds in stratigraphic position and general lithologic features with the Codell sandstone. Similar sandstone at the top of the Carlile has also been found farther south in the Walsenburg quadrangle. The Carlile is there darkgray shale, 170 to 180 feet thick, with 10 to 15 feet of yellow sandstone at the top, capped by bituminous

\footnotetext{
${ }^{47}$ Waldschmidt, W. A., Characteristics of older Cretaceous formations of northeastern Colorado: Am. Assoc. Petroleum Geologists Bull., vol. 17 , no. 4 , pp. $415-416,1933$.

${ }^{48}$ Mather, K. F., Gilluly, James, and Lusk, R. G., op. cit. (Bull. 796), p. 81 .

8 Gilb
}

limestone 2 to 4 feet thick. Still farther south, in the Spanish Peaks quadrangle, the Carlile includes 200 feet of dark-gray shale which grades near the top into 10 feet of sandy shale and friable yellowish sandstone, with an overlying layer of purplish bituminous limestone 1 to 2 feet thick.

The top of the Carlile, as observed by the writers on the north side of the Huerfano River in the extreme western part of the Walsenburg quadrangle, includes a considerably greater thickness of sand than is given in published descriptions. There is at least 25 feet of medium-hard light-gray fine-grained sandstone, buff colored and nodular-weathering in the lower part. Above this is 9 feet of soft sand and sandy shale, and at the top a bed 2 feet thick of hard brown-weathering gray limestone, which has an irregular under surface, contains abundant broken fossils and shark teeth, and at the top appears to be interbedded with thin streaks of soft sandy shale.

Sandstone at the top of the Carlile as a persistent lithologic unit apparently does not extend southward into New Mexico, however, for at a locality northwest of Vermejo Park (on Gold Creek west of old Pinafore post office) the upper part of the Carlile consists of yellowish-gray shale with septarian concretions and a few thin beds of hard, somewhat sandy, highly fossiliferous limestone.

The Codell sand is a source of nonflowing artesian water in a large area north of the Arkansas River, especially in the vicinity of Eads and Chivington, but the water is not potable and in some wells is unfit for stock use.

Nine samples of water were collected in the vicinity of Eads and Chivington from wells that obtain water from the horizon of the Codell sand. Partial analyses by the water-resources branch of the United States Geological Survey show that all the samples have a large amount of dissolved mineral matter. The smallest amount of total dissolved solids in any sample was 1,700 parts per million and the greatest was over 10,000 parts per million; most of them were between 2,500 and 6,500 parts. In all the samples the calcium carbonate content was small, which is surprising in view of the fact that the Codell is overlain by 50 feet or more of limestone and locally itself contains calcareous beds. The principal mineral constituents are sodium salts, bicarbonate, chloride, and sulphate. There is, however, a large difference in the relative amounts of these constituents, even in wells that are a mile or less apart, a difference difficult to explain unless it is assumed that there is little or no lateral movement in the aquifer. A greater number of samples and a more complete analysis of each will be necessary before any tentative conclusions can be drawn as to the nature of the water movement. 


\section{POSSIBILITY OF UNCONFORMITY AT TOP OF CODELL}

The Codell sandstone clearly represents the widespread occurrence of a set of environmental conditions different from those under which the deposition of the underlying rocks of Benton age occurred, or from those under which the overlying Niobrara formation was laid down. The Graneros and Greenhorn formations particularly give evidence that the sediments which compose them were deposited in moderately deep water, almost certainly below the depth of wave agitation-for individual beds even of small thickness persist for considerable distances. The lower part of the Carlile is also evenly bedded, but much of the Codell was clearly deposited within the reach of wave and current agitation. This is shown not only by its sandy composition but also by the irregularity and cross-bedding which in places appear within it. Ripple marks have been observed at some places, and the shark teeth locally present are worn by abrasion. In a larger way the differences in lithology of the member from place to place indicate that it was deposited under the variable conditions to be expected in a shallow-water environment.

Although in many places thin and possibly locally absent, the Codell is surprisingly widespread, extending over most of eastern Colorado and western Kansas, with little significant variation in content or bedding. The Codell therefore seems to represent a time when deposition had filled a large area of the Cretaceous sea to a level at which the deposited material was within the reach of wave agitation. There is reason to believe that this condition was maintained for a considerable period.

Johnson ${ }^{50}$ has already summarized the evidence for an unconformity at the base of the overlying Niobrara formation, concluding that "Sufficient time, at least * * * elapsed to account for a complete cessation of deposition of one type, its alteration, and, in places, partial erosion and the development of conditions under which sediment of a completely new type was deposited." Certainly the abrupt change in fauna from the Carlile to the Niobrara suggests, even if the difference in lithologic character of the formations is discounted, that there was a lapse of time that permitted the development of new faunas.

Johnson also cites as evidence of unconformity a "thin conglomerate containing plentiful fish teeth, wellrounded pebbles, and phosphate nodules" which "occurs at the base of the Niobrara in all the areas studied." The pebbles are described as small, smooth, and well rounded, some as much as 3 inches in diameter. They consist chiefly of black chert but also of quartzite and

\footnotetext{
${ }^{5}$ Johnson, J. H., Unconformity in Colorado group in eastern Colorado: Am. Assoc. Petroleum Geologists Bull., vol. 14, no. 6, pp. $789-794,1930$.
}

white quartz, and they occur together with phosphate nodules and shark teeth in a matrix of gray to brown crystalline sandy limestone. Although pebbles are also reported at this horizon in southeastern Colorado, none were observed by the writers in the outcrops extending from La Junta eastward to the Kansas State line. The possibly similar bituminous limestone with some shark teeth (and phosphatic nodules?) occurring there at the top of the Carlile has already been described (p. 217). This rock is, however, faunally and lithologically allied with the Codell, to which it is assigned by the writers. The base of the overlying Niobrara formation is for the most part sharp and locally slightly irregular. Angular discordance was nowhere observed. Particularly from T. 22 S., R. 53 W., to T. 22 S., R. 51 W., however, the basal contact of the Niobrara is somewhat obscure. The hard brown limestone assigned to the Codell by the writers appears to grade upward into the overlying gray or white limestone, and locally lenses of hard brown limestone like the underlying rock also appear in the basal Niobrara. Also the brown limestone itself becomes somewhat lighter colored eastward. The gradation, in fact, is so pronounced that the hard brown limestone has been interpreted by Patton ${ }^{51}$ as merging into the basal limestone bed of the Niobrara. Patton supposed that the occurrence near the bottom of the Niobrara of a fossil identified as Inoceramus labiatus, a characteristic Benton form, reinforced this interpretation. It is now known, however, that an Inoceramus much like Inoceramus labiatus but distinct from it is present in many places in the lowest beds of the Niobrara. On the whole the appearance of the contact itself as seen by the writers neither suggests nor disproves unconformable relations.

In some areas local thinning of the Carlile suggests the possibility that the thinning may be due to erosion in those areas before the deposition of the Niobrara. Notably in the vicinity of La Junta the Carlile is abnormally thin. A section measured by Patton ${ }^{52}$ shows a thickness of 130 feet. The logs of wells at Cheraw and Swink indicate that the Carlile is about 125 feet thick. (See fig. 10.) The logs of other wells in the vicinity of La Junta show that the beds of Benton age are from 50 to 75 feet thinner than to the east or west, and this thinning presumably also is due entirely to thinning of the Carlile. To the west, the Carlile is from 210 to 225 feet thick in the Nepesta quadrangle ${ }^{53}$ and 200 to 232 feet thick in the Apishapa quadrangle; ${ }^{54}$ east of Las Animas it is probably over 200 feet thick, and in Hamilton County, in western Kansas,

\footnotetext{
${ }^{51}$ Patton, H. B., op. cit., pp. 18, 21.

52 Idem, p. 17

${ }^{53}$ Fisher, C. A., U. S. Geol. Survey Geol. Atlas, Nepesta folio (no. $135)$, p. 2, 1906.

5 Stose, G. W., U. S. Geol. Survey Geol. Atlas, Apishapa folio (no. $186)$, p. 6, 1912.
} 
about 250 feet thick. If the writers' view is accepted, that the hard brown limestone above described is to be assigned to the Codell, the thinning of the Carlile in the vicinity of La Junta takes place within the Carlile and not as a result of erosion at the base of the overlying Niobrara. The thinning is thus presumably to be ascribed to lesser deposition in that area. The sandy phase of the Codell thins out over the same area, but its diminution from 30 feet to the vanishing point is not adequate to explain the total thinning of 50 to 75 feet, part of which must therefore be due to thinning of lower beds in the Carlile. Lest the thinning of the sandy Codell westward be interpreted as due to erosional unconformity at the base of the hard brown limestone, it should be pointed out that the sandy phase appears to merge westward into nonsandy beds by intertonguing and also that the distinctive zone of septarian concretions at the top of the Blue Hill shale member appears to maintain approximately its vertical distance from the base of the Niobrara across the area in which there is no Codell sand. (See fig. 11.) For some reason, therefore, the area about La Junta appears to have received less sediment than the surrounding regions. A plausible explanation for similar features in the Benton stratigraphy in other areas in eastern Colorado has already been offered by Johnson and Aurand..$^{55}$ They suggest that structural features in existence during early Cretaceous time were rising slowly throughout Benton time, sufficiently high to divert or check the velocity of the submarine currents. "Part of the time their tops seem to have been approximately at the plane of equilibrium, where, though the waters were free to pass over them, there was almost no erosion or deposition, though deposition was taking place around the sides."

As neither the local thinning of the Carlile and absence of the Codell member nor the details of the contact between the Niobrara and Carlile offer incontrovertible evidence of unconformity at the base of the Niobrara, the writers believe that the most valid evidence of such unconformity is the faunal discontinuity between the two formations. There seems no reason to suppose that the top of the Carlile emerged above sea level and was eroded. The faunal discontinuity seems rather to indicate a period at which the top of the Carlile sediments stood at wave base, with submarine erosion counterbalancing deposition. This was followed by subsidence or the deepening of the sea waters from some more remote cause, and in these less agitated waters the calcareous sediments of the Niobrara were deposited.

55 Johnson, J. H., and Aurand, H. A., A preliminary contribution to the Benton paleogeography of eastern Colorado: Am. Assoc. Petroleum Geologists Bull., vol. 13, no. 7, pp. 850-853, 1929.

\section{FAUNA}

Fossils collected from the Fairport and Codell members include the following forms:

Codell sandstone member: Locality Inoceramus fragilis Hall and Meek

Inoceramus dimidius White $1,2,3,7$

Inoceramus sp

Ostrea lugubris Conrad. 7

Ostrea $\mathrm{sp}_{-}$

Gryphaea sp_

Scaphites warreni Meek and Hayden

Prionocyclus wyomingensis Meek_

Lamna? sp

Ptychodus sp

Fairport chalky shale member:

Inoceramus $\mathrm{sp}$

Ostrea sp

Baculites sp

Exiteloceras cf. E. pariense (White)

Prionotropis woolgari (Mantell)

$1,2,3,5,6,7$

1. 15746, Colorado City, west of Colorado Springs.

2. 15758, NW$^{1} / 4$ sec. 24 , T. 9 S., R. 68 W., Perry Park.

3. $15820, \mathrm{SW}^{1} / 4$ sec. 9 , T. 22 S., R. $501 \mathrm{~W}$.

4. $15823, \mathrm{SE} 1 / 4$ sec. 35 , T. 21 S., R. 50 W.

5. $16066, \mathrm{SW}^{1 / 4}$ sec. 32 , T. 21 S., R. 48 W.

6. $16070, \mathrm{NE} 1 / 4$ sec. 6, T. 22 S., R. 44 W.

7. $16084, \mathrm{NE} 1 / 4$ sec. 26 , T. 21 S., R. 49 W.

8. $15822, \mathrm{NE}_{1} / 4$ sec. 16, T. 22 S., R. 50 W.

9. 16067, SE $1 / 4$ sec. 27 , T. 21 S., R. 49 W.

10. 16074 , northeast corner sec. 34 , T. 21 S., R. 49 W.

Bass ${ }^{56}$ reports from the lower 18 feet of the Fairport shale member of Hamilton County, Kans., the follow. ing species: Globigerina bulloides D'Orbigny, Inoceramus fragilis Hall and Meek, Inoceramus labiatus Schlotheim (broad variety), Ostrea cf. O. congesta Conrad, Baculites gracilis Shumard, Prionotropis woolgari (Mantell), Ichthyodectes? sp. From the Blue Hill shale member Bass ${ }^{57}$ reports Inoceramus sp. (fragments) and Prionocyctus wyomingensis Meek. From the top of the Codell Bass ${ }^{58}$ reports Inoceramus fragilis Hall and Meek, Ostrea congesta Conrad (float?), Prionocyclus wyomingensis Meek, Ptychodus sp., Lamna? sp., Corax? sp., coprolites, and phosphate nodules.

\section{NIOBRARA FORMATION}

The Niobrara formation is the uppermost formation of the Colorado group. It is distinctly separated from the underlying Carlile shale but less readily separable from the overlying Pierre shale, the lowest formation of the Montana group. It includes about 700 feet of beds, chiefly chalk and chalky shale but with a wellmarked, persistent limestone member, from 50 to 65 feet thick, at the base. This limestone is continuous in outcrop with the limestone member of the Niobrara

${ }^{5}$ Bass, N. W., op. cit., p. 66.

53 Idem, pp. 64-65.

58 Idem, p. 65. 


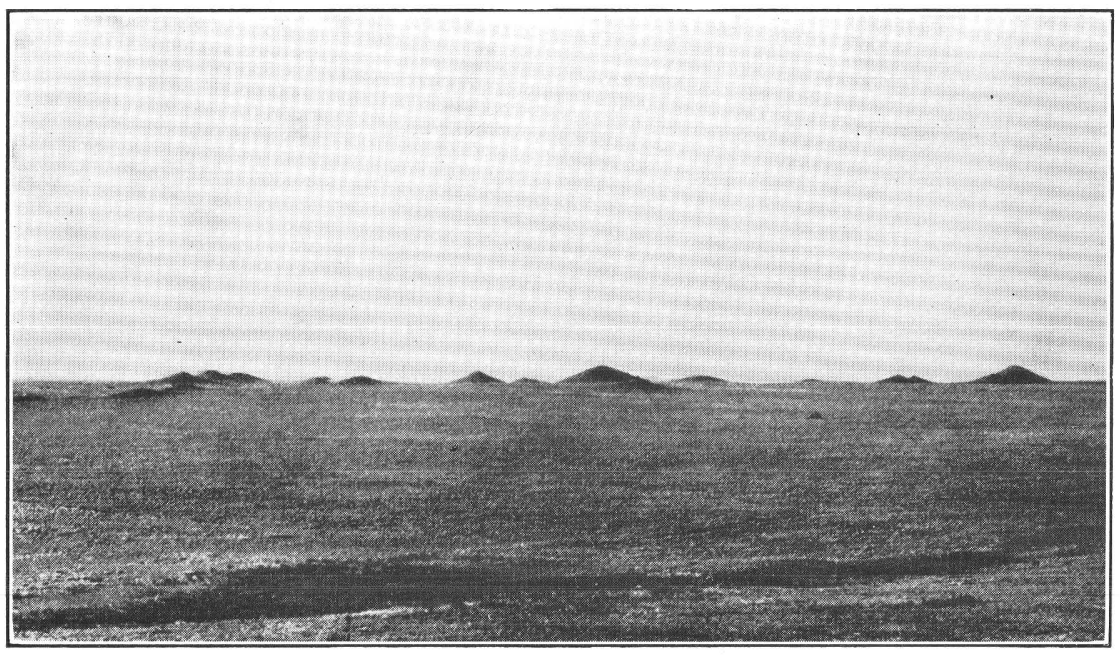

A. A GROUP OF "TEPEE BUTTES."

Small conical hills in the Pierre shale formed by the greater resistance to weathering of large masses of
limestone. Looking north from the center of sec. 3, T. 17 S., R. 65 W.

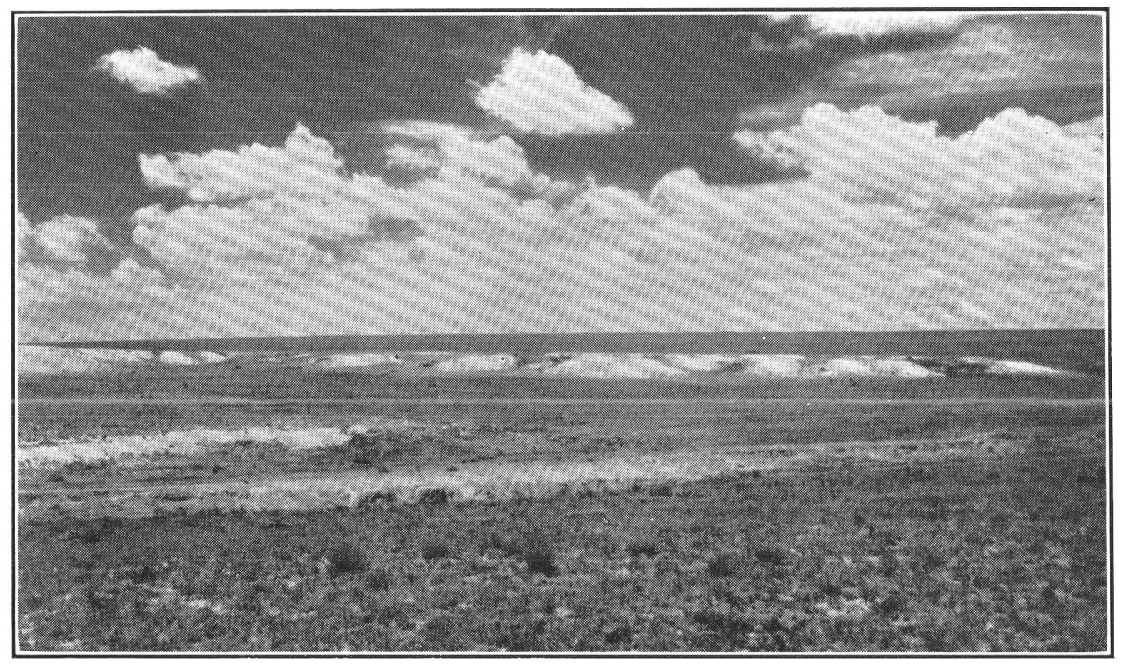

C. TYPICAL OUTCROP OF THE LOWER PAR'T OF THE SMOKY HILL MARL MEMBER OF THE NIOBRARA FORMATION.

Looking northwest from the SW1/4 sec. 16, T. 21 S., R. 49 W.

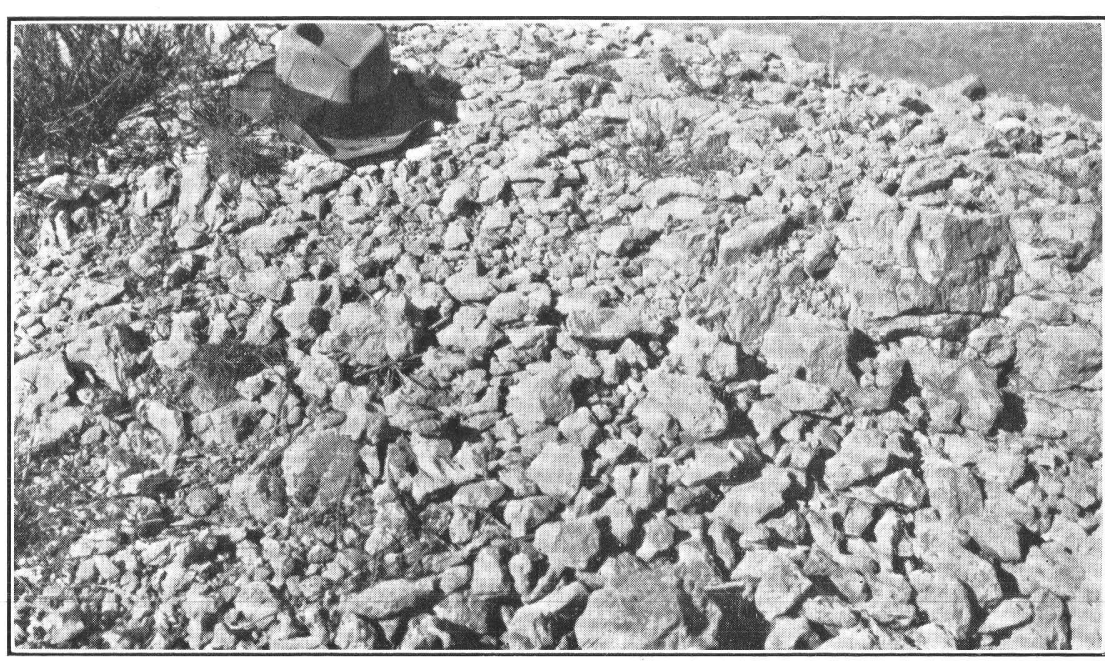

B. DETAILED VIEW OF WEATHERED TOP OR CORE OF A "TEPEE BUTTE" IN THE NE1 SEC. 35 , T. 12 S., R. 49 W.

The rock is an impure limestone in which Lucina occidentalis is exceedingly abundant.

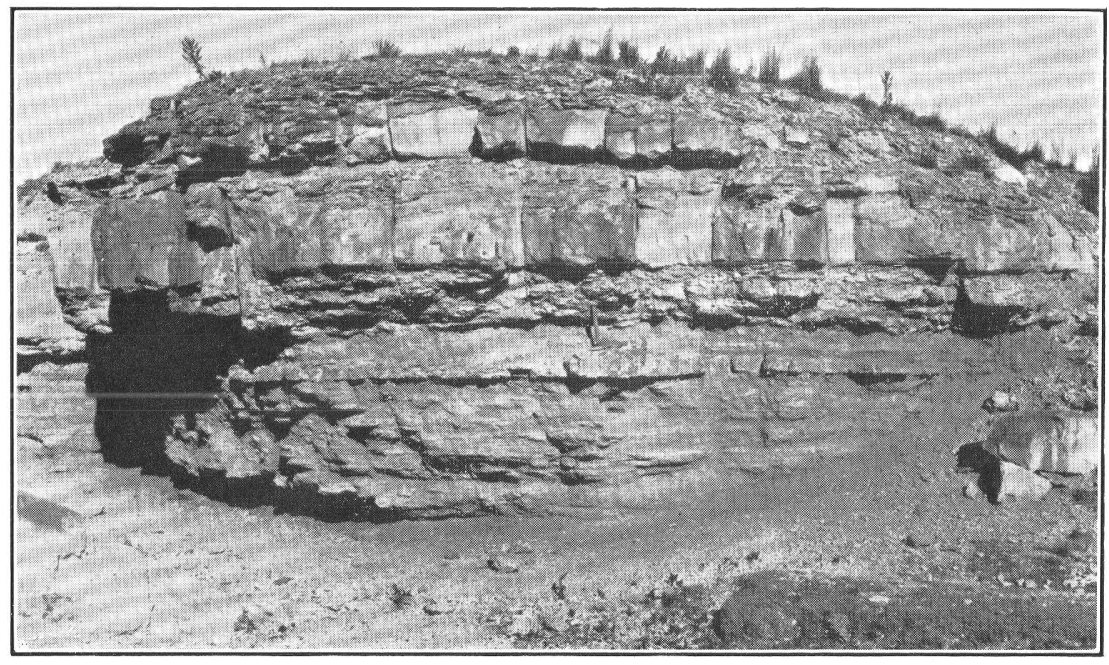

D. CONTACT BETWEEN THE HAYS LIMESTONE MEMBER OF THE NIOBRARA FORMASEC. 21 , T. 21 S., R. $49 \mathrm{~W}$.

The hammer rests on a hard bed of calcareous sandstone within the Codell, about 2 feet below the base 

formation in western Kansas that has long been called "Fort Hays limestone" and is equivalent to it in lithology, thickness, and age, so far as known. The writers propose that the limestone at the base of the Niobrara within the area which they have mapped be called the "Hays ${ }^{59}$ limestone member" and that the overlying portion of the Niobrara be called the "Smoky Hill marl member", to correspond with the usage of "Smoky Hill" for the upper chalk member of the Niobrara formation in the adjoining area of western Kansas.

The Niobrara formation of southeastern Colorado has heretofore been divided into a lower member, the Timpas limestone, and an upper member, the Apishapa shale. These previously defined units differ somewhat from those recognized in western Kansas and from those recognized by the writers north of the Arkansas River in eastern Colorado.

According to Stose,$^{60}$ the Timpas limestone was named by Gilbert from Timpas Creek, which flows through the southeast corner of the Apishapa quadrangle and thence into the Arkansas River. The description of the Timpas limestone by Gilbert ${ }^{61}$ is quoted below, in part:

The general thickness of the Timpas is $\mathbf{1 7 5}$ feet; and it may be characterized as a series of limestones and calcareous shales with prevailing pale colors.

At the base is a limestone series about 50 feet thick. The individual beds range in thickness from a few inches to 3 feet, the average being about 1 foot. They are separated by layers of gray shale, usually 1 or 2 inches thick. The limestone has a light-gray color, which becomes creamy white on weathered surfaces. It is compact and rather fine grained and where exposed to the weather breaks up into rough flakes, of which the longer dimensions are parallel to the bedding. This peculiarity ordinarily serves to distinguish it from the Greenhorn limestone, which cleaves into vertical plates. $* * *$ In its lower layers are small nodules of iron sulphide, which are converted by the chemical reaction of the air to limonite. As the limestone is broken up and removed by the action of weather, the more resistant nodules are freed from their matrix so as to lie loose on the surface. They are of a dark-brown color and of oval or cylindrical form, with a diameter of about half an inch. Their surfaces are not even but are set with angular projections, the end of crystals. ***

The upper limit of the limestone is indefinite. It passes gradually into a light-gray limy shale, which contains occasional thin beds of limestone and has a total thickness of 100 or 125 feet, terminating at top in one or two layers of chalky limestone containing several species of fossil shells and also the remains of fishes.

The Hays limestone member as recognized by the writers is probably closely equivalent to the "limestone

\footnotetext{
59 The shorter name "Hays" has been adopted for this member with the approval of R. C. Moore, State geologist of Kansas. The name of the type locality has for some time been "Hays."

${ }^{60}$ Stose, G. W., U. S. Geol. Survey Geol. Atlas, Apishapa folio (no. $186)$, p. 6, 1912 .

${ }^{61}$ Gilbert, G. K., The underground water of the Arkansas Valley in eastern Colorado: U. S. Geol. Survey 17th Ann. Rept., pt. 2, pp. $566-567,1896$.

$77388-37-3$
}

series about 50 feet thick" at the base of the Timpas as defined in earlier reports. In the region mapped, and in some sections examined in adjoining areas, the limestone unit about 50 feet thick forms a natural, convenient, and practicable unit. It is, moreover, the unit readily recognizable in records of deep wells, both in this area and in northeastern Colorado. ${ }^{62}$

The Timpas was differentiated in the La Junta region, ${ }^{63}$ but farther east the limestone bed at the top of the Timpas was not recognized with assurance nor mapped by the writers. This may be in part attributable to scarcity and discontinuity of exposures. Two limestone beds, each 1 foot or less in thickness and separated by 12 feet of cream-colored or tan chalk, are exposed in the eastern part of sec. 23, T. 23 S., R. 55 W., and may lie near the top of the Timpas formation as previously defined. In the eastern part of sec. $27, \mathrm{~T}$. 21 S., R. 53 W., along Adobe Creek, there is a bed of white limestone about 4 feet thick underlain by chalk which may also be near the same horizon. These limestone beds are included by the writers in the Smoky Hill marl. Even were exposures adequate, there is some doubt that the Timpas limestone as previously defined is a stratigraphic unit of widespread usefulness within the area described by the writers.

Inoceramus deformis, which is abundant in the Hays limestone member, does not occur above it, and immediately overlying beds contain large flat Inoceramus (Haploscapha) grandis. These fossils appear to have distinct ranges over most of the region of western Upper Cretaceous sedimentation, regardless of lithologic environment. There is thus some suggestion that the lithologic unit of the Hays limestone is also a faunal unit. The unit named "Timpas limestone" by Gilbert therefore includes in its upper part beds that are both lithologically and faunally more closely allied to the upper part of the Niobrara. The names "Timpas" and "Apishapa" have, however, been applied to mappable units over a large area west and southwest of the area in which the writers have had opportunity to make detailed observations and should therefore be retained for areas in which the propriety of distinguishing the Hays limestone member has not yet been made evident.

\section{HAYS LIMESTONE MEMBER}

The term "Fort Hays" (from the former fort of that name in Ellis County, Kans.) was first used by Mudge ${ }^{64}$ as a division name, defined thus: "The massive stratum of limestone above described, together with all the deposits above the sandstone of the Dakota, I shall call the Fort Hays division." This included all the strata

${ }^{62}$ Waldschmidt, W. A., op. cit., pp. 412-415.

${ }^{63}$ Patton, H. B., op. cit., pp. 43-44.

${ }^{64}$ Mudge, B. F., Notes on the Tertiary and Cretaceous periods of Kansas: U. S. Geol. and Geog. Survey Terr. 9th Ann. Rept., p. 289, 1877. 
from the top of the Dakota to the base of the present Smoky Hill member. Williston ${ }^{65}$ later restricted the name to include only the present Hays limestone member.

The Hays limestone member includes beds of white to cream-colored, chalky limestone 6 inches to 3 feet thick separated by beds of gray calcareous shale 1 to 6 inches thick. The limestone makes up nearly threefourths of the member. Near the base there are numerous small irregular or capsule-shaped nodules of pyrite (or marcasite?) from one-fourth to three-fourths of an inch in longest dimension. The surface of these nodules is made up of an aggregate of interlocking cubical crystals. In the lower foot or two of the member there are small lenses of hard gray limestone which have a petroliferous odor on fresh fracture and resemble the limestone bed that in places forms the top of the Codell sandstone member of the Carlile.

The following section of the Hays limestone member was measured approximately midway east and west within the area covered by the map:

Section of Hays limestone member of the Niobrara formation in secs. 16 and $21, T .21 \mathrm{~S} .$, R. $49 \mathrm{~W}$.

Niobrara formation.

Smoky Hill marl member:

Shale, tan; weathers yellow.

Limestone, white

Shale, chalky, gray to tan; weathers tan-

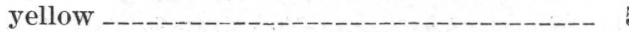

Hays limestone member:

Concealed, limestone and shale________... 17

Shale, chalky, light tan.

Limestone, white

Limestone and shale, interbedded, partly concealed

Limestone, white; contains Inoceramus deformis and fucoids

Limestone, white, chalky, and gray shale

Limestone, white, chalky, irregular bedding.

Chalk, shaly, white to gray

Limestone, white

Shale, gray to tan; contains many Inoceramus deformis?

Limestone, white, chalky

Chalk, white

Limestone, white; weathers into small tabular pieces

Chalk, shaly

Limestone, white

Shale, tan to gray; contains Inoceramus sp --

Limestone, white; lower 2 feet massive

Chalk, shaly, tan to gray

Limestone, white

Chalk, tan

Limestone, white

Shale, chalky, tan

Shale, blue

Limestone, white

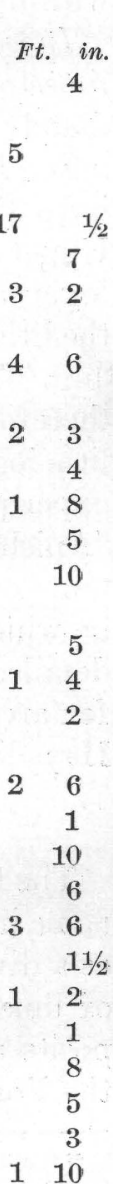

${ }^{65}$ Williston, S. W, The Niobrara Cretaceous of western Kansas: Kansas Acad. Sci. Trans., vol. 13, pp. 108-109, 1893.
Section of Hays limestone member of the Niobrara formation in secs. 16 and $21, T .21$ S., R. 49 W.-Continued

Niobrara formation-Continued.

Smoky Hill marl member-Continued.

Chalk, tan, and limestone

Ft. in.

Limestone, white

Shale, greenish gray

15

Limestone, white

Chalk, tan

Limestone, white

Shale, blue gray, calcareous

Limestone, white; weathers into tabular pieces

Shale, gray, chalky

Limestone, white; contains abundant Inoceramus deformis

Chalk, tan, and gray calcareous shale_......

Limestone, white_-_-_-_-_-_-_-_-_-_-_-_-

Chalk, tan

Limestone, white

Shale, gray, calcareous

Limestone, white

Chalk, tan to gray

Limestone, white; irregular bedding; weathers into tabular pieces

Shale, tan, chalky

Limestone, white

Chalk, light gray, shaly_

Limestone, white, irregular

Chalk, light gray, shaly

Limestone, white

Limestone, white, and tan chalk

Limestone, white

Chalk, tan, shaly

Limestone, white

Shale, tan, chalky

Limestone, white, containing capsule-shaped pyrite nodules

Carlile shale:

Codell sandstone member:

Sandstone and shale, gray, cemented with lime; contains lenses of hard limestone----

Sandstone, gray to brown, hard; contains fish scales, fragments of fossils, and fucoids. From 0 to

Sandstone; gray, fine-grained.

Total measured $\begin{array}{ll}71 & 8\end{array}$

Thickness of Hays limestone

$64 \quad 4$

The thickness of the Hays in the above section is about 65 feet. In Hamilton County, Kans. ${ }^{66}$ the thickness of the member is 61 feet. In the Nepesta quadrangle ${ }^{67}$ and adjoining areas the thickness of the limestone unit at the base of the Timpas is about 50 feet.

The Hays limestone is much more resistant to weathering than the beds above or below and consequently generally forms an escarpment or cliff. It is exposed almost continuously from La Junta to a point north of McClave. Thence eastward, however, it is poorly exposed. East of Lamar the base of the lime-

${ }^{66}$ Bass, N. W., op. cit., p. 62

${ }^{67}$ Fisher, C. A., op. cit., p. 2. 
stone swings southward across the Arkansas River but swings back before the Kansas line is reached.

\section{SMOKY HILL MARL MEMBER}

Although the entire thickness of the Smoky Hill marl member is present, little is known of it in detail because of poor exposures (pl. 65, $C$ ). It lies upon the white chalky limestone beds of the Hays member, from which it is easily distinguishable because it is softer and has a characteristic yellowish-orange color. The Smoky Hill contains beds of white limestone, but they are in most places only a few inches thick and are separated by much greater thicknesses of yellowish chalk. Several thin bentonite beds have been noted within the Smoky Hill, as well as beds of dark-tan and bluish shale. Much of the Smoky. Hill has a tan to yellow color when fresh, and practically all of it has some shade of yellowish orange on weathered exposures. Another distinguishing feature is the occurrence of small white calcareous flecks throughout the chalk, which give it a mottled "salty" appearance. The total thickness of the Smoky Hill is not known precisely, but from well logs it is believed to be between 600 and 700 feet. Within probably the upper 100 feet of this member are chalk beds that are somewhat harder and purer than the beds below. On weathered outcrops the bedding planes have opened, and these horizontal or tabular spaces are loosely filled with needlelike interstitial calcite in which the larger dimension of the crystals is perpendicular to the bedding. As a whole, the Smoky Hill is well stratified and thinbedded. It is practically all calcareous, but the larger part of it may be properly termed marl rather than chalk.

Inoceramus (Haploscapha) grandis is the most diagnostic fossil of the Smoky Hill member. Complete well-preserved specimens are seldom found, but in places large fragments covered with oyster shells are numerous. Fish scales are abundant in some exposures of the upper part of the member.

\section{NIOBRARA FORMATION IN SOUTHERN FOOTHILL REGION}

The Timpas limestone has been differentiated as far south as the area of the Spanish Peaks folio, ${ }^{68}$ in which it is described as 200 feet thick, including a lower portion, 45 to 50 feet thick, consisting chiefly of limestone. Just a short distance to the south, along the east flank of the Sangre de Cristo Range in extreme northern New Mexico, however, limestone forms a much smaller proportion of the Niobrara formation, as shown in the following section:

${ }^{68}$ Hills, R. C., U. S. Geol. Survey Geol. Atlas, Spanish Peaks folio (no. 71), p. 1, 1901 .
Section of Niobrara formation on Gold Creek, west of old Pinafore post office, northwest of Vermejo Park on the road to Costilla, Colfax County, N. Mex.

Pierre shale.

Niobrara formation:

Shale, hard, gray, calcareous; thickness (esti- Ft. in. mated) 250

Shale, hard, gray, calcareous, with a zone of thin lenticular beds of hard gray calcareous sandstone near the top; thickness (estimated) _-_. 500 )

Limestone, gray, in beds 4 inches to 1 foot 4 inches thick, with intervening beds of gray calcareous shale

Shale, gray, calcareous

Bentonite

Shale, gray, calcareous

Bentonite

Shale, gray

Bentonite

Shale, gray, calcareous, with thin lenses and beds of hard gray marl

Rusty streak.

Shale, gray, calcareous__-_-_-_-_._-

Bentonite

Shale, gray, calcareous, some thin shaly limestone beds.

Bentonite?

Shale, gray, calcareous

Bentonite

\section{8}

1

10

5

7
Thickness of Niobrara formation, about_- 770

Carlile shale: Gray shale with septarian concretions and thin beds of hard sandy limestone.

This section is of interest in representing the character of the Niobrara formation at a place probably near the southwesterly limit at which a limestone unit equivalent to the Hays limestone of the Arkansas Valley is present in the Cretaceous section.

The rather conspicuous bentonite zone in the basal part of the Niobrara in the preceding section has not been described in previously published reports and was not observed by the writers along the Arkansas River. There is a suggestion, however, that it extends some distance northward along the east flank of the Sangre de Cristo Range into Colorado. Bentonite beds, probably in the basal part of the Niobrara, were observed at a locality about 6 miles south of Stonewall, in western Las Animas County, Colo. (west of Trinidad). Still farther north, on the north side of the Huerfano River just northeast of the bridge at Badito, there is a soft concealed interval of 10 feet above the sand at the top of the Carlile shale. At the top of the concealed interval are soft bedded marls, and at the base of it there may be some bentonite. The softer beds making the interval of concealment were included by the writers in the Niobrara formation. 


\section{FAUNA}

The following fossils were collected by the writers from the Niobrara formation:

Smoky Hill marl member:

Inoceramus $\mathrm{sp}_{-}$

Locality

Inoceramus deformis Meek?

Inoceramus aff. $I$. stantoni Sokolow?

Ostrea congesta Conrad.

Baculites codyensis Reeside

Fish remains, undetermined

Hays limestone member:

Globigerina $\mathrm{sp}$

Inoceramus deformis Meek

Inoceramus aff. I. stantoni Sokolow

Ostrea congesta Conrad.

Ostrea $\mathrm{sp}$

Scaphites ventricosus Meek and Hayden

1. $16071, \mathrm{NE} 1 / 4$ sec. 6 , T. 22 S., R. $44 \mathrm{~W}$.

2. $16080, \mathrm{NW}^{1} / 4$ sec. 19 , T. 20 S., R. $43 \mathrm{~W}$.

3. 15745 , Mount Morrison-Bear Creek locality. (See p. 210.)

4. 15747, Colorado City, west of Colorado Springs.

5. 15751, Cuesta ridge on east flank of small anticline on Arkansas River about 7 miles west of Pueblo.

6. $15811, \mathrm{SE} 1 / 4$ sec. 24 , T. 22 S., R. $53 \mathrm{~W}$.

7. 16073, NW $1 / 4$ sec. 32 , T. 21 S., R. 44 W.

8. 16075, SW $^{1 / 4}$ sec. 27 , T. 20 S., R. 49 W.

9. $16079, \mathrm{NW} 1 / 4$ sec. 17 , T. 19 S., R. 44 W.

10. $16081, \mathrm{SE} 1 / 4 \mathrm{SE} 1 / 4$ sec. 26 , T. 20 S., R. $43 \mathrm{~W}$.

11. 16082 , NW $1 / 4$ SW $1 / 4$ sec. 34 , T. 17 S., R. 44 W.

The late Prof. I. A. Keyte collected from beds at a horizon near the top of the Apishapa shale (top of Smoky Hill member of this paper), southwest of the area treated here, the following forms: Pelecypods, Inoceramus sp., Turnus n. sp.; gastropod, Anchura? sp.; cephalopods, Eutrephoceras sp., Baculites asper Morton, Baculites codyensis Reeside, Scaphites vermiformis Meek and Hayden, Scaphites ventricosus Meek and Hayden with several varieties, Placenticeras sp., Texanites cf. T. pseudotexanus (Grossouvre). G. K. Gilbert collected from the upper part of the Niobrara northwest of Pueblo a very large specimen of Inoceramus undulatoplicatus Roemer.

\section{PIERRE SHALE}

The lower part of the Pierre shale is present in the area shown on the map (pl. 64). It is poorly exposed, but lithologic subdivisions can be recognized and can be traced through the scattered outcrops available for examination. Much of the upper part of the formation lies outside of the area shown on plate 64 , and the uppermost beds are not treated in detail in this paper, though certain data on these beds that have been collected are given on pages 230-231.

\section{LOWER PART}

Several divisions have been recognized in the lower part of the Pierre shale of eastern Colorado and in that of western Kansas by previous students of these areas. It does not yet appear possible, however, to establish definite correlations between the series of units set up in the several areas. As set forth below, the writers propose to apply in the Arkansas Valley only one formal member name, the "Sharon Springs shale member", using for the present only informal names for other divisions.

Before describing the exposures of the lower part of the Pierre in the mapped area, however, it seems best to describe the nature of this part of the Pierre shale farther west, where exposures are more complete.

The lower part of the Pierre shale is well exposed along the south side of Little Fountain Creek in the northern part of sec. 18, T. 16 S., R. 66 W., about 6 miles somewhat south of west from the town of Fountain, in the Colorado Springs quadrangle. The Pierre and underlying Niobrara dip generally eastward and northeastward at angles of $10^{\circ}$ to $15^{\circ}$, the dip diminishing toward the east. The basal portion of the Pierre includes an estimated thickness of 550 feet of thinbedded dark-gray shale. There are a few thin beds of hard yellowish-gray sandy limestone and a few beds a small fraction of an inch thick of yellowish earthy sand, also a few beds of bentonite. The only fossil remains observed were fish scales. At the top of this lithologic unit, near the center of the north line of sec. 18 , there is a zone of large gray septarian concretions, seamed with brownish crystalline calcite. Immediately above this zone lie brownish-gray and dark-gray shales, with numerous reddish-brown calcareous beds and small flattish red-brown concretions. This lithology continues upward for an estimated thickness of 450 feet, and at the top the shales contain numerous fossils, chiefly Inoceramus sagensis $\mathrm{Owen}$ and Baculites ovatus Say.

The general subdivision of the lower part of the Pierre described above was also recognized by Gilbert ${ }^{69}$ in the vicinity of Pueblo. He says:

The Barren zone, so called on account of the rarity of its fossil remains, lies at the bottom of the series and is 400 to 500 feet thick. It is of bluish-gray color and in its lower part resembles the Niobrara shale in the tendency to divide into papery layers, rough from the crystallization of selenite. The Rusty zone, 600 feet thick, is also bluish gray in color but is comparatively free from gypsum. It contains many concretions composed of lime carbonate and iron carbonate, and these are of oval form, measuring, usually, from 1 foot to 2 feet across. Their material is originally dark gray but under the action of the weather turns a rusty brown, and the soil derived from the formation is usually so strewn with their angular fragments as to appear reddish brown. The Baculite zone, 100 to 200 feet thick, is pale gray and is so called from the abundance of a fossil shell of that name.

The "Barren zone" and "Rusty zone" of the Pierre are also recognized and described by Lavington, ${ }^{70}$ who

${ }^{69}$ Gilbert, G. K., U. S. Geol. Survey Geol. Atlas, Pueblo folio (no. $36)$, p. 3,1897 .

${ }^{70}$ Lavington, C. S., Montana group in eastern Colorado: Am. Assoc. Petroleum Geologists Bull., vol. 17, no. 4, pp. 398-400, 1933. 
states that they are present in the Canon City-Florence district. Lavington ${ }^{71}$ believes that in northeastern Colorado the Baculite zone recognized by Gilbert is not persistent over widespread areas.

In the Nepesta quadrangle, which lies to the east of the Pueblo quadrangle, Fisher ${ }^{72}$ recognized in the Pierre a basal black shaly "barren zone", 400 to 500 feet thick, succeeded by 500 feet of dark-gray shale with numerous rusty concretions of iron and lime carbonate, and this in turn by 100 to 200 feet of somewhat lighter gray shale with numerous baculites.

Eastward to the Kansas line in the area shown on the map (pl.64) small isolated outcrops show that the divisions recognized above carry through eastward. Some 2.4 miles north of Olney Springs are outcrops of shale with rusty concretionary beds and gray septarian concretions, representing a zone 300 to 350 feet above the base of the Pierre shale. These outcrops are probably near the base of the "rusty zone" and indicate a somewhat diminished thickness of the basal "barren zone", which is not exposed in this locality. Outcrops near the base of the Pierre in a large ditch in the southwest corner of sec. 29, T. 20 S., R. 56 W., northeast of Lake Henry, consist chiefly of thin-bedded gray and dark-gray shale that is neither sandy nor calcareous. One thin bed of white bentonitic clay and two beds of red clay less than 1 inch thick were observed, and also a few yellowish and slightly sandy beds. About 3 miles northeast of Lake Henry, in the bank of Pond Creek where it crosses the line between secs. 16 and 17, T. 20 S., R. $56 \mathrm{~W}$., are outcrops of shale which are estimated to be not more than 300 feet above the base of the Pierre. The lower part of the exposure consists of gray and dark-gray bedded shale, slightly sandy toward the top. The upper part consists of gray somewhat sandy shale and gray shale with abundant yellow and brown resinous fragmentary remains of fishes. One reptilian rib, possibly that of a mosasaur, was observed. There are some sandy layers. At the base of the upper part is a layer of soft white bentonitic clay. In the upper part of the exposure are large dark-gray dense limestone concretions. This exposure apparently represents the top of the basal "barren zone" of the Pierre. Although it is not definitely known to be immediately overlain. by beds in which the rusty-weathering carbonate concretions are abundant, the next overlying exposures exhibit the "rusty zone" lithology.

The basal portion of the Pierre is exposed also west and northwest of Haswell. The beds are mostly dark nonsandy shales with numereous gypsum crystals, though there are a few thin purplish-brown concretionary beds and some bentonite-beds, of which one has a thickness of $3 \frac{1}{2}$ inches. In the NW1/4 sec. 16,

${ }^{71}$ Lavington, C. S., op. cit., p. 403.

${ }^{2}$ Fisher, C. A., op. cit., p. 2.
T. 18 S., R. 52 W., a zone of large gray dense septarian limestone concretions in gray shale is succeeded upward by shale in which the dark reddish-brown "rusty zone" concretions are abundant. These exposures may represent the top of the basal "barren zone" of the Pierre, which cannot much exceed 200 feet in thickness in this vicinity.

In the area intervening between the exposures northeast of Lake Henry and the exposures west of Haswell no outcrops having the lithology of the basal Pierre were observed. In the $\mathrm{NW}^{1} / 4$ sec. $14, \mathrm{~T} .18 \mathrm{~S}$, R. $54 \mathrm{~W}$., there are exposures of shale with abundant rusty-brown concretions less than 2 miles west of topographically higher exposures of calcareous shale that apparently belongs to the Niobrara formation. It seems more likely that this occurrence is due to a somewhat steeper northwestward dip at this place than to absence of the "barren zone."

In the western part of sec. 29, T. 15 S., R. 46 W., an exposure shows calcareous concretions with septaria of crystalline calcite embedded in gray to black nonsandy shale with much soft powdery gypsum. This exposure may also represent the top of the "barren zone" of the basal Pierre.

Detailed studies in Wallace County, Kans., enabled Elias ${ }^{73}$ to subdivide the lower part of the Pierre into several members, the lowest of which, the Sharon Springs member, conforms in lithology with the "barren zone" of the Pierre of eastern Colorado. The Sharon Springs member is 155 feet thick. It is overlain by the beds called "Weskan member" by Elias, which are succeeded by his Lake Creek member and that in turn by his Salt Grass member. These three members are characterized by abundant limonitic concretions, which have a rusty appearance. They have a combined thickness of 430 feet and appear to be equivalent to the "rusty zone" of the Pierre of eastern Colorado.

The writers propose to extend the name "Sharon Springs member" into eastern Colorado to include the basal black-shale member above described, which is equivalent to the "barren zone" previously recognized. They feel that the overlying "rusty zone" has not yet been sufficiently studied or its upper limit in Colorado determined with sufficient accuracy to warrant designation by a specific name.

Although the Sharon Springs member as above defined appears to be a widespread and homogeneous unit of black clay shale which is present also in the northern foothill region and is recognized by drillers in northeastern Colorado, ${ }^{74}$ scattered observations indicate that the lowest part of the Pierre may be more variable in its lithologic features in the southern foothill region.

${ }^{78}$ Elias, M. K., The geology of Wallace County, Kans. : Kansas Geol. Survey Bull. 18, pp. 58-116, 1931.

${ }^{74}$ Lavington, C. S., op. cit., p. 399. 
On the north side of Apache Creek, $11 / 2$ miles southwest of Hayden Butte, in the Walsenburg quadrangle, there are extensive exposures of an earthy sandstone about 60 feet thick. Near the middle is a zone of large limestone concretions. Below the sandstone dark shale with rusty concretionary beds a few inches thick is exposed for 50 feet, more or less, and above it lie black thin-bedded shales with some rusty streaks. The exact stratigraphic position of the exposures was not ascertained, but they are clearly in the lower part of the Pierre, possibly about 500 feet above the base. Inoceramus sagensis Owen and Baculites asper Morton were collected from concretions about 5 feet above the top of the sandstone.

On the north side of the Huerfano River 3 miles northeast of Badito there are exposures of an earthy gray and buff well-bedded sandstone, for the most part well indurated, with some brown concretionary beds. Overlying the sandstone is 5 feet of sandy shale with a concretionary zone at the top from which Inoceramus sagensis Owen, Baculites asper Morton, and Scaphites nodosus Owen var. were collected. This concretionary zone is overlain by black paper-bedded shales that contain a few rusty concretionary beds. Below the sandstone there is sandy shale with some rusty concretionary beds and a few yellow flattish concretions 1 foot thick and as much as 20 feet in length. The interval from the sandstone described to the top of the Niobrara was not determined but is probably more than 300 feet. The two exposures of sandstone described may be the Apache sandstone of Prommel. ${ }^{75}$

Still farther south, at a locality 6 miles north of Stonewall, road cuts expose the lower part of the Pierre shale, which at this place dips vertically. Although penetrated by sills of dark igneous rock and possibly somewhat squeezed and faulted, these exposures give a good idea of the lithology of the lower part of the Pierre. A carefully estimated section is as follows:

Section of Pierre shale 6 miles north of Stonewail

Pierre shale:

Shale, black __________ 200

Sandstone, fine-grained, earthy, lumpy-bedded, and sandy shale

Shale, slightly sandy. In the upper part are two beds of yellow-weathering concretionary limestone and a few thin streaks of shaly limestone

Shale, light gray, lumpy-bedded, with some small rusty concretions

Concealed

Shale, like that exposed next above---D--

Shale, black, thin-bedded. In the basal part are a very few thin sand streaks

Thickness exposed 100

Niobrara formation: Shale, calcareous, with a thin dense impure limestone bed in the upper part.

${ }^{75}$ Lavington, C. S., op. cit., p. 399.
In the western part of the town of Pueblo, 0.6 mile north of the Arkansas River and 0.6 mile east of Dry Creek, outcrops of the basal part of the Pierre reveal a sandy lithology not observed in areas to the north or east. At this place the exposures display alternating beds of dark-gray shale and yellowish-weathering sandy shale, overlain by at least 10 feet of very fine grained yellow earthy sand, some beds of which are soft, though others are cemented by lime to a hard coherent rock. This sandy zone may be as much as 300 feet stratigraphically above the highest exposures of Niobrara observed by the writers, but as it appears to lie near to or even below the Niobrara-Pierre contact as mapped by Gilbert, the sand presumably lies in the basal part of the Pierre. These beds contain fish scales and numerous macerated plant remains, together with a few invertebrate fossils. (See collection 15753, p. 230.)

\section{UPPER PART}

In the area north of the Arkansas River a wholly satisfactory lithologic or faunal subdivision of the Pierre above the "rusty zone" is difficult to make. In part this is due to the absence of readily distinguishable differences or reliable key beds in the thick mass of shaly rocks. In part also it is due to the wide expanse of exposure with low dip and broadly level topography, with a resulting lack of extensive vertical exposures. There is also much concealment by younger unconformable Tertiary and later deposits. The differentiation of the Pierre is further complicated by the fact that the original thickness of the formation diminished by several thousand feet across the area which is now eastern Colorado.

Several previous writers have differentiated the "tepee zone" of the Pierre, distinguished by the presence of "tepee buttes"-small, sharply conical hills, formed by the superior resistance to weathering of large concretionary masses of limestone. (See pl. 65, $A, B$.) As defined by Gilbert, ${ }^{76}$ the zone is 1,000 feet thick, overlying the "Baculite zone" and including the upper part of the Pierre as exposed in the Pueblo quadrangle. According to Fisher's description of the Pierre of the Nepesta quadrangle, the zone is 500 feet thick, underlain as in the Pueblo area by about 1,200 feet of shales but overlain by about 600 feet of lightgray sandy shales.

Two zones of tepee buttes were recognized near Fountain by Lavington. ${ }^{77}$ East of Hugo, in the southwestern part of T. 11 S., R. 52 W., there are large concretionary masses much like tepee cores, but probably having less vertical than horizontal extent. These occur

${ }^{76}$ Gilbert, G. K., U. S. Geol. Survey Geol. Atlas, Pueblo folio (no. $36)$, p. 3, 1897.

${ }^{77}$ Lavington, C. S., op. cit., p. 402. 
several hundred feet above the main series of tepee buttes.

In the vicinity of Fountain, in the Colorado Springs quadrangle, the writers estimated that the "tepee zone" was roughly 1,500 feet thick and the overlying portion of the Pierre shale was also 1,500 feet thick. As these estimates agree moderately well with the thicknesses of 1,275 feet for the "tepee zone" and 1,885 feet for the overlying Pierre shale measured by Lavington, ${ }^{78}$ the writers believe that their estimate of 2,000 feet of the Pierre shale below the "tepee zone" west of Fountain and south of Little Fountain Creek may be correspondingly reliable. The total thickness of the Pierre in the Colorado Springs region is therefore about 5,000 feet. If these estimates are correct, the "tepee buttes" occur considerably lower in the section in the Pueblo region, where they are found at horizons beginning 1,200 feet above the base of the Pierre and only 200 feet above the top of the "rusty zone."

As the total thickness of the Pierre is known to diminish greatly southward from Colorado Springs, ${ }^{79}$ the lower occurrence of "tepee buttes" in the Pueblo region may be due to thinning of the 1,000 feet of shaly beds below the "tepee zone" in the vicinity of Fountain to about 200 feet near Pueblo. In fact, Lavington ${ }^{80}$ believes that on the west side of Baculite Mesa, northeast of Pueblo, small conical buttes from the overlying "tepee zone" actually range down into the "rusty zone." The "tepee zone" also apparently thins southward from Colorado Springs to Pueblo and eastward from Pueblo to about 500 feet in the Nepesta region and in the region north of Olney Springs, Ordway, and Arlington. In this region also the interval between the base of the "tepee zone" and the top of the "rusty zone" is apparently less than 100 feet. The base of the zone in which "tepee buttes" occur is about 1,350 feet above the base of the Pierre southwest of Boyero and about 1,100 feet above the base north of Kit Carson. Exclusive of the Sharon Springs member and the overlying "rusty zone" at these places the intervening part of the Pierre shales below the "tepee zone" thins eastward from perhaps 650 feet southwest of Boyero to 400 feet north of Kit Carson. It should be understood that the thicknesses given above are estimates only.

Because the "tepee buttes" occur in widely separated groups and because the concretions that form them are embedded in shale in which no distinguishable lithologic or faunal zones have yet been discovered, there is no real assurance that these concretions are actually confined to a stratigraphically definable zone in the Pierre shale. Nevertheless, from their distribution it,

${ }^{78}$ Lavington, C. S., op. cit., fig. 1.

${ }^{7}$ Hills, R. C., U. S. Geol. Survey Geol. Atlas, Walsenburg folio (no. $68)$, p. 2, 1900 .

80 Lavington, C. S., op. cit., pp. 399-400. seems probable to the writers that they are restricted to a certain zone whose limits differ somewhat from place to place, that this zone diminishes southeastward in thickness, and that the shales below it but above the "rusty zone" also diminish southeastward in thickness.

In form, the tepee buttes, as their name implies, are low conical hills rising above the general level of the surrounding country. At the top of each is an irregular cap of light-gray or brown limestone, much fractured and containing great numbers of fossil shells, among which Lucina occidentalis is everywhere predominant. The shells are more or less completely recrystallized to translucent or transparent calcite, normally with a yellowish cast, and the containing rock is in places seamed with intersecting veinlets of similar calcite. On some of the buttes the limestone rock reveals a poorly defined, irregular horizontal stratification. The slopes of most of the buttes expose the shale in which the limestone masses are embedded, but almost all of them are thickly strewn with disintegrated fragments of the hard rock exposed at the top. It is obvious that the topographic form of the buttes is due to the greater resistance to erosion of the central capping mass of limestone. As the result of the most critical study of the origin of the tepee buttes which has been made, Gilbert and Gulliver ${ }^{81}$ concluded that the limestone masses had the general form of vertical cylindrical cores, and this conclusion has been followed by all subsequent observers. Inasmuch as it seems to the writers that the same topographic form might well be produced by an essentially equidimensional concretionary mass, it is unfortunate that exposures of the vertical dimension of the tepee cores are rare. The greatest height of a core actually observed by Gilbert was 18 feet, and the horizontal dimensions of this core were not stated. In only one tepee butte examined by the writers could it be definitely ascertained that the vertical dimension was greater than the horizontal.

Tepee cores have, however, been reported to have vertical dimensions of as much as 50 feet, $^{82}$ and the shape of one core has been described as tapering downward like an inverted cone.

The tepee-core rock has been described as follows: ${ }^{83}$

The tepee rock is essentially a calcium carbonate, the ratio of calcium carbonate to magnesium carbonate being 18 to 1 in the single sample analyzed. That sample contained also 12 percent of argillaceous material. For comparative purposes, analyses were also made of the enclosing shale and of one of the ordinary concretions of the shale, the determinations showing that the tepee rock does not differ materially in composition from the concretions, and that the argillaceous material is practically identical with the shale. This permits us to regard

81 Gilbert, G. K., and Gulliver, F. P., Tepee buttes : Geol. Soc. America Bull., vol. 6, pp. 333-342, 1895.

${ }^{82}$ Fisher, C. A., U. S. Geol. Survey Geol. Atlas, Nepesta folio (no. $68)$, p. 2, 1906.

${ }^{88}$ Gilbert, G. K., and Gulliver, F. P., op. cit., pp. 336-337. 
the argillaceous material as included shale, and therefore an impurity rather than an essential constituent of the tepee rock.

The rock has a coarse texture, breaks with rough fracture, and its general color is a light, warm gray. It is full of fossil shells, and the microscope shows that they are embedded in a matrix which is composed of fragments of shell, water-worn grains of calcite, Foraminifera, and clay. Cross sections of Lucina shells show that the original shell structure remains, although the lime of the shell has been recrystallized into calcite. Inside of the shell wall there is a band of radiating crystals of calcite, showing well-marked spherulitic structure. The calcareous ooze which must have at first occupied the central cavity of the shell has recrystallized into very pure calcite, leaving the clay impurities at one side of the shell. This central calcite crystal is the same individual which has replaced the lime of the shell, for the two parts extinguish together, the cleavage cracks extend from the center through the outside, and when the spherulitic band is faulted the clear calcite is continuous through the cracks. Experiments showed the spherulitic layer to be slightly less soluble in dilute hydrochloric acid than the clearer calcite.

In a few thin sections examined by the writers there is considerable variation in the nature of the rock. On the whole, the proportion of shell material is much less than half of the total bulk. In some of the Lucina shells there is a division of the shell into three zonesan outer band that is composed of relatively few calcite crystals, a wider central layer of fibrous calcite with flamboyant extinction, and an inner layer of variable thickness which consists of small calcite crystals interlocking in a granular mass that grades into the matrix filling the shell. This granular layer is not common, and where it is absent the fibrous layer grades into the matrix. The fibrous layer may also be absent from either one or both valves of the shell, but the outer layer of large calcite crystals retains a sharp boundary with the shell filling, although it may be partly or wholly replaced by chlorite. No central ealcite crystals were observed within the matrix that fills the shells.

The bulk of the rock is fine-grained, consisting of intimately intermixed clay and calcite. Although the distribution of these materials varies greatly, there is a marked tendency for the clay to occur in somewhat darker, cloudier patches, in cross section having a circular, elliptical, or irregular shape. These clay patches range from 0.1 to 1 millimeter in diameter in different slides examined but exhibit less size variation in individual slides. Although the appearance of some of them suggests a coprolitic origin, it seems probable that most of them may represent flocculated clay pellets. In some slides granular interlocking areas of calcite occur in a fine-grained clay-calcite matrix; darker patches, chiefly of clay, occur in the same type of matrix; and patches of clay occur in areas of more coarsely crystalline calcite. Some of the clay patches are irregular and bounded by areas of calcite grains with crystal outlines. These irregular clay masses seem to be segregations produced during recrystallization of the rock.
Brown, darkly translucent or black opaque organic matter of various types occurs in small and broken fragments throughout much of the rock. In some areas, notably in the matrix within one Lucina shell near the hinge and within the outer calcite layer of another Lucina shell, in lines paralleling the shell banding, are minute nearly black grains, 15 to 50 microns across, which from their crystal form were pyrite, but which because of their slight translucency and reddish-brown color in reflected light now appear to be of limonitic composition. The writers' thanks are due to C. S. Ross, of the Geological Survey, for confirmatory examination of these grains and some advisory comments on the nature of the rock in general.

The clastic content of the rock is small and variable, some slides showing virtually none and others having an appreciable amount of very angular grains of quartz, feldspar, and accessory ferromagnesian minerals. The grains observed were as much as 0.2 millimeter in diameter.

Foraminifera were observed in most of the slides but are not numerous.

Gilbert ${ }^{84}$ concluded that the most satisfactory explanation of the tepee cores was that each "was the site of a colony of Lucina and that the remains of each perishing generation furnished in some way conditions favorable to the life of the next", although he considered that knowledge of the tepees at that time was not sufficient to definitely establish this as the correct explanation. Some of the difficulties in accepting the theory of colonial origin, as above outlined, were pointed out by Gilbert. In the first place the predominant shell of the tepee cores, Lucina, is neither known to be a colonial species nor to be a species that would especially flourish on the presumably more stable foundation afforded by the shells and broken shell fragments of preceding generations. Lucina occurs in some abundance in the adjoining shales and is found elsewhere in sandy shales and sandstones. Some of the shells in the tepee cores are wholly embedded in the matrix and in general are no more commonly adjacent to or resting on other shells than would be expected from their relative abundance in the rock. Nor is it known that individuals of Lucina at any stage utilized or required an attachment. In the second place, the bulk of the material of the tepee cores is fine-grained calcite and clay, which gives no indication of being of organic origin, except for the possible coprolitic structures mentioned above.

On the other hand, the slight differences observed between the matrix within and outside the shells and other features of the rock suggest that it is an original sedimentary deposit rather than a concretionary aggregate, and the particular abundance of Lucina shells

s4 Gilbert, G. K., and Gulliver, F. P., op. cit., p. 339. 
indicates contemporaneously favorable life conditions of some sort for them.

It seems possible that such favorable conditions might be provided by submarine springs of low volume but relatively high concentration in calcium carbonate. It has already been pointed out by Gilbert ${ }^{85}$ that springs of sufficient volume to build a tufalike core would produce a concentric structure in the cores, which has not been found. On the other hand, a spring or seep of low volume on the sea floor might simply provide an abundance of mineral salts in solution, which would produce locally a favorable site for the growth of many kinds of organisms. A feature of the distribution of the buttes, which might be construed as favoring the hypothesis of submarine springs, is their tendency to alinement in rows. The lines of buttes in various places trend in diverse directions, so that this tendency to alinement does not produce any discernible systematic arrangement of the tepees as a whole, but locally the alinement is pronounced and should be explained by any satisfactory theory of their origin, as should also the tendency of the buttes to occur in groups or clusters.

As an interesting speculation, the writers advance the hypothesis that the predicated submarine springs arose from the pressing out of connate water during the compaction of the sediments deposited to the north in the more rapidly subsiding portion of the Denver Basin. The "tepee zone" contains the same fauna in general as the Hygiene sandstone member and overlying sandstone members in the Pierre shale of the northern foothills, where the total thickness of the Pierre shale is much greater. These sandstones alternate with intervening shalier zones and diminish in thickness southward and southeastward. As they were deposited in the more rapidly subsiding portion of the basin, the tapering margins of the sandy wedges would gradually acquire a gentle upward slope to the southeast, outward and upward from the basin. It seems possible that with the compaction of the sediments connate water of high mineral content would be squeezed out of muds and sandy silts into overlying tongues of sand that might then serve as channel courses for the movement of water upward and southward, there to escape upward through the soft sediments of the sea floor along local lines of weakness. H. F. Davies ${ }^{86}$ has suggested a more direct relationship of the tepee buttes to the Hygiene and other sandstones, supposing that they may represent offshore deposition of the colloidal silica and calcium carbonate left in solution at the outer margins of deposition of the sandy materials.

Whatever the actual mode of origin of the tepee cores, if their vertical dimension is materially greater

85 Gilbert, G. K., and Gulliver, F. P., op. cit., p. 339.

${ }^{20}$ Lavington, C. S., op. cit., p. 402. than their horizontal dimension, it seems that there must have been a balance of some sort between the rate of deposition of the surrounding sediments and the rate of accumulation of the tepee core rock, in order that the required conditions for forming that rock might persist in one locality through the long period of time that must have been required to build up the tepee core and deposit the surrounding shale. That there were some variations in conditions from time to time is seen by the irregular nature of some exposed side walls of cores. In Gilbert's words, they "exhibit shoulders, shelves, and overhangs, besides being rugose in detail." In general, it may be concluded that such conditions could be maintained only in places where the rate of shell and calcium carbonate accumulation could keep pace with the rate of sedimentation. Where sediments accumulated more rapidly nearer the source of supply, such conditions could not long be maintained. On the other hand, the rate of accumulation of the shells would also seem to be a variable one, depending on available supplies of necessary materials for shell construction

The foregoing discussion of the origin of the tepee cores is intended primarily to emphasize the point that the nature of the masses themselves indicates that they represent a type of deposition which would occur at a certain time within a geographically limited belt, and that this belt of tolerance would be very likely to migrate to and fro, owing to variations in the rate of supply of the sandy sediment that was being deposited farther north and to variations in the rate of subsidence of the basin. If so, the shale that contains the tepee cores probably has an intertonguing relation with the enclosing shales that are barren of the tepee masses.

The part of the Pierre shale above the "tepee zone" is composed of sandy shale and soft sandstone, particularly in the upper part. It is lithologically a transition unit from the dominantly fine sedimentary beds of the Pierre shale to the sandstone of the Fox Hills. As will be seen from the faunal lists below, it is likewise in its upper part a transition zone from the faunal assemblage characteristic of the Pierre shale to that characteristic of the Fox Hills sandstone. Neither top nor base of this transition zone is sharply defined, but it is certainly some hundreds of feet thick and appears to be characterized faunally by Inoceramus fibrosus (Meek and Hayden), Baculites grandis Hall and Meek, and several species of Discoscaphites. It is notable that in this region in the upper part of the transition zone and in the base of the overlying Fox Hills sandstone an association of such forms as Inoceramus sagensis Owen and Baculites grandis Hall and Meek with the Discoscaphites and species of Sphenodiscus is not uncommon. In other regions where Pierre and Fox Hills are recognized this association is so rare as to be virtually nonexistent. 
FAUNA

The fossils collected from the Pierre shale by the writers are listed below. The first list contains fossils from the beds between the transition zone and the base of the "tepee zone", with the exception of collections $15752,15753,15757,15864$, and 15962, which came from the lower part of the formation. The second list includes fossils from the transition zone in the uppermost part of the Pierre.

\section{Fossils from the Pierre shale below the transition zone}

Locality

Cliona sp., borings

Inoceramus barabini Morton

Inoceramus sagensis Owen

$7,8,5,6$,

$3,21,24$

Inoceramus sp__ $14,20,28,29,30,31$

Ostrea cf. O, congesta Conrad________________ 24, 28

Anomia sp, probably new.

Lucina occidentalis Morton_______ $9,10,15,17,23,25,26,28,30$

Lucina subcrassa Meek and Hayden.

Lucina sp

25

Mactra gracilis Meek and Hayden______________ 4,30

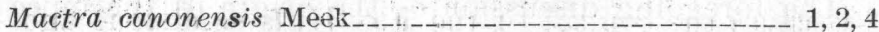

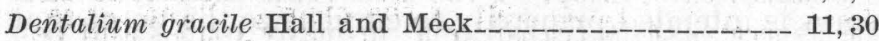

Lunatia dakotensis Henderson_____________ 30

Aporrhais $\mathrm{sp}_{-} \ldots$

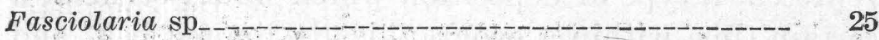

Anchura sp_________ 16, 29?

Baculites compressus Say___________________ 9,31

Baculites ovatus Say____ 2, 7, 25, 30

Baculites ovatus Say var. haresi Reeside____________ 5, 26

Baculites sp______ 11, 12, 16, 27, 28, 29

Exiteloceras? sp

Didymoceras ef. D. beecheri Hyatt

Parapachydiscus complexus (Meek)

Acanthoscaphites nodosus (Owen) typical form_____ 31

Acanthoscaphites nodosus (Owen) var__._._. 1, 9, 10, 20, 28

Acanthoscaphites quadrangularis (Meek) _.___________ 24, 27

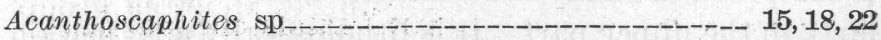

Placenticeras meeki Boehm

Hypsodon? radiatulus Cockerell

1. 15732, Leyden Gulch, north of Golden, about 5,000 feet above the base of the Pierre.

2. 15733 , Leyden Gulch, nearly the same as 15732 .

3. 15734, Leyden Gulch, nearly the same as 15732 .

4. 15735 , Leyden Gulch, nearly the same as $\mathbf{1 5 7 3 2}$.

5. 15752, opposite Piñon station, 6.2 miles north of Eden on Pueblo-Colorado Springs highwaý.

6. 15753, west of Pueblo, north of Arkansas River, east of Dry Creek Valley.

7. 15757 , northeast corner sec. 18 , T. 16 S., R. 66 W., south of Little Fountain Creek, southwest of Colorado Springs.

8. $15759, \operatorname{SE} 1 / 4$ sec. 15 , T. 15 S., R. 65 W., at bridge on abandoned railroad grade.

9. 15750 , near center of sec. 3 , T. 17 S., R. 65 W., 1 mile southeast of Little Buttes.* ${ }^{87}$

10. $15809, \mathrm{NW}^{1} / 4$ sec. 19 , T. 15 S., R. $57 \mathrm{~W}$.

11. 15810 , secs. 14 and 23 , T. 17 S., R. 55 W.

12. 15812, NE $1 / 4$ sec. 27 , T. 15 S., R. 55 W.

13. 15841 , along highway, sec. 3 , T. 11 S., R. $54 \mathrm{~W}$.

${ }^{87}$ Collections made from the core rock of tepee buttes are indicated by asterisks.
Fossils from the Pierre shale below the transition zone-Contd.

14. 15843 , SW $1 / 4$ sec. 36 , T. 13 S., R. 56 W. 15. 15847 , NE $1 / 4$ sec. 30 , T. 13 S., R. 56 W. 16. $15854, \mathrm{NW}^{1} 1 / 4$ sec. 26 , T. 14 S., R. $55 \mathrm{~W}$. 17. 15855, SW $1 / 4$ sec. 14, T. 14 S., R. 57 W. 18. $15858, \mathrm{NE}^{1 / 4}$ sec. 36 , T. 10 S., R. 53 W. 19. $15859, \mathrm{NE}^{1} 1 / 4$ sec. 34 , T. 10 S., R. $52 \mathrm{~W}$. 20. $15860, \mathrm{SE} 1 / 4$ sec. 30 , T. 10 S., R. 51 W. 21. $15861, \mathrm{NE} 1 / 4$ sec. 26 , T. 8 S., R. 50 W. 22. 15862, SE $1 / 4$ sec. 35 , T. 9 S., R. 51 W. 23. $15863, \mathrm{SE}^{1} / 4$ sec. 28 , T. 11 S., R. $52 \mathrm{~W}$.

24. 15864 , NW $1 / 4$ sec. 22 , T. 13 S., R. 51 W.

25. 15755, 3.1 miles north of Belle Plaine, which is 2.7 miles east of Fountain Creek at Pueblo.

26. 15756 , same locality as 15755,40 feet higher.

27. 15808 , sec. 1 , T. 21 S., R. 59 W., 5.3 miles north of Olney Springs.*

28. 15813, 2.6 miles south of Karval.

29. $15962, \mathrm{NE} 1 / 4$ sec. 34 , T. 14 S., R. 67 W., 500 feet above base of Pierre.

30. $15963, \mathrm{SW}^{1} / 4$ sec. 20 , T. 14 S., R. 66 W., brick pit southeast of Colorado Springs.

31. $16072, \mathrm{NW}^{1} / 4 \mathrm{NE}^{1} / 4$ sec. 1 , T. 13 S., R. 47 W.*

Fossils from the "transition zone" of the Pierre shale

Locality

Robulus sp $5,10,20,27$

Serpula? sp_______

Lingula sp________________________ 3,8

Solemya bilix White______ 3

Nucula planimarginata Meek and Hayden________ 3, 4, 8, 13

Nucula larimerensis Reeside___________._._._._. 18

Nucula $\mathrm{sp}_{-}$

Yoldia scitula Meek and Hayden____________ 28

Yoldia evansi Meek and Hayden________ 3, 4, 5, 6, 15, 19, 28

Yoldia $\mathrm{sp}$

Perissonota? $\mathrm{sp}_{-}$

Inoceramus sagensis Owen_____________ 20, 22, 28, 31, 36

Inocoramus altus Meek?

Inoceramus fibrosus (Meek and Hayden) _..._._. 4, 6, 7,9,

$10,11,12,16,17,18,22,25,30,31$

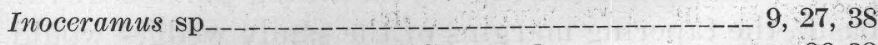

Pteria nebrascana Evans and Shumard________ 26, 32

Pteria $\mathrm{sp}$

Pecten nebrascensis Meek and Hayden___________ 28

Lima n. sp., several____________ 4

Crenella elegantula Meek and Hayden_________ 14

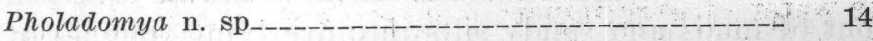

Cuspidaria ventricosa Meek and Hayden__._________ $4 ; 8$

Veniella humilis Meek and Hayden________ 19

Eriphyla gregaria Meek and Hayden?___________ 3

Lucina occidentalis Morton____ 10, 23, 27, 30

Lucina $\mathrm{sp}_{-}$

Protocardia subquadrata Evans and Shumard_____ 4, 15, 17

Tellina scitula Meek and Hayden

Mactra gracilis Meek and Hayden_________._. 1, 2, 11, 13,

$22,28,34,35,36,38,40,41$

Mactra canonensis Meek

Mactra sp______________ 14, 17

Dentalium gracile Hall and Meek

Dentalium $\mathrm{sp}_{-}$

Lunatia dakotensis Henderson_________ 3, 9?, 20, 33

Lunatia $\mathrm{sp}$

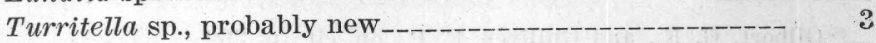

Fasciolaria? cf. $F$. cheyennensis Meek and Hayden $\ldots \ldots+\ldots, 20$ 
Fossils from the "transition zone" of the Pierre shale-Contd.

Locality

Anchura? sp

Haminea subcylindrica (Meek)

Cinulia (Oligoptycha) concinna Hall and Meek

Baculites sp____ $7,17,28,34,35,36,37,38,40$ ?

Discoscaphites conradi (Morton)

Discoscaphites cheyennensis (Owen)

Discoscaphites mandanensis (Morton) $-30,39$

Discoscaphites cf. D. abyssinus (Morton) $5,17,22$

Discoscaphites cf. D. nicolleti (Morton)

Discoscaphites sp $4,6,7,8,9,11,16,18,20,22 ?, 23,27$

Acanthoscaphites $\mathrm{sp}$ 33 ?, $35,37 ?$

Sphenodiscus lenticularis (Owen)

Belemnitella bulbosa Meek and Hayden.

Decapod crustacean, undetermined.

1. 15802, north tributary of Fountain Creek, north of Colorado Springs.

2. $15806, \mathrm{SW}^{1} 1 / 4$ sec. 35 , T. 13 S., R. $58 \mathrm{~W}$.

3. 15814, 15.1 miles north of Limon on Brush road.

4. 15815, 15.1 miles north of Limon on Brush road, above 15814.

5. 15816, 21.3 miles from Limon, just east of road bridge across Beaver Creek on road to Agate.

$615825, \mathrm{NE}^{1} 1 / 4$ sec. 24 , T. 2 S., R. 55 W.

7. 15826, 9.1 miles north of Last Chance store.

8. 15827 , NE $1 / 4$ sec. 15 , T. 3 , S., R. 56 W.

9. $15828, \mathrm{SW}^{1} 1 / 4$ sec. 5 , T. 2 S., R. $55 \mathrm{~W}$.

10. $15830, \mathrm{NW}^{1} / 4$ sec. 6 , T. 10 S., R. $55 \mathrm{~W}$.

11. 15832 , SE $1 / 4$ sec. 36 , T. 9 S., R. 55 W.

12. 15834 , NW $1 / 4$ sec. 30 , T. 9 S., R. 55 W.

13. 15804, one-eighth mile north of southeast corner sec. 3 , T. 14 S., R. 58 W.

14. $15838, \mathrm{SW}^{1} / 4$ sec. 33 , T. 3 S., R. 58 W.

15. 15842, northeast corner sec. 1, T. 2 S., R. 58 W.

16. 15844 , SW $1 / 4$ sec. 7 , T. 2 S., R. 53 W.

17. 15845, SW1/4 sec. 29, T. 11 S., R. 56 W., East Rush Creek.

18. 15848, NW $^{1 / 4}$ sec. 6 , T. 2 N., R. 55 W.

19. 15849 , southwest corner sec. 1 , T. 5 N., R. 59 W.

20. 15850 , center sec. 4 , T. 13 S., R. 57 W., Rush Creek.

21. $15851, \mathrm{NE}^{1 / 4}$ sec. 30 , T. 13 S., R. 58 W., Little Horse Creek.

22. $15852, \mathrm{~S}^{1 / 2}$ sec. 20 , T. 13 S., R. $58 \mathrm{~W}$.

23. $15853, \mathrm{~N}^{1} / 2$ sec. 26 , T. 12 S., R. $56 \mathrm{~W}$.

24. $15856, \mathrm{~S} 1 / 2$ sec. 7 , T. 14 S., R. $57 \mathrm{~W}$.

25. $15857, \mathrm{NW}^{1} 1 / 4$ sec. 13 , T. 14 S., R. 58 W., Horse Creek.

26. 15875 , SW $1 / 4$ sec. 16 , T. 8 N., R. 57 W.

27. 15876, E1/2 sec. 4, T. 8 N., R. 55 W., South Pawnee Creek.

28. 15956 , SW $1 / 4$ sec. 31, T. 13 S., R. 66 W., Monument Creek north of Colorado Springs.

29. 15961 , center SW $1 / 4$ sec. 30 , T. 13 S., R. 66 W.

30. $15969, \mathrm{SE} 1 / 4$ sec. 3 , T. 1 N., R. 43 W., 3 miles east of Wray.

31. $15971, \mathrm{NW}^{1} / 4$ sec. 6 , T. 2 S., R. 42 W.

32. $16307, \mathrm{SE}^{1} / 4$ sec. 5 , T. 3 S., R. $57 \mathrm{~W}$.

33. 15955 , SW $1 / 4$ sec. 21 , T. 14 S., R. 66 W., 2 miles southeast of Colorado Springs.

34. $15957, \mathrm{NW}^{1 / 4}$ sec. 31 , T. 13 S., R. 66 W., Monument Creek, north of Colorado Springs.

35. 15958, NW1/4 sec. 31, T. 13 S., R. 66 W.

36. $15960, \mathrm{NW} 1 / 4$ sec. 31 , T. 13 S., R. $66 \mathrm{~W}$.

37. 15970, near center sec. 21 , T. 2 S., R. 43 W.

38. $15805, \mathrm{NW} 1 / 4$ sec. 2 , T. 14 S., R. 58 W., bank of Horse Creek 250 feet east of bridge.

39. $15836, \mathrm{NE}^{1 / 4}$ sec. 13 , T. 9 S., R. $56 \mathrm{~W}$.

40. 15803 , line between secs. 3 and 10, T. 14 S., R. 58 W.

41. $15807, \mathrm{E} 1 / \frac{2}{2}$ sec. 33 , T. 13 S., R. 58 W.

\section{FOX HILLS SANDSTONE}

The Fox Hills sandstone, which overlies the Pierre shale, outcrops north and northwest of the area shown on plate 64 . Its geographic distribution and some features of its stratigraphic relations with the Pierre shale are briefly discussed in another paper ${ }^{88}$ dealing with the later Cretaceous formations of the Denver Basin. Because of the faunal relationships between the transition zone of the Pierre shale and the Fox Hills sandstone it is desirable to include in this paper a summary of identifications of fossils collected from the Fox Hills.

As used by the writers the name "Fox Hills sandstone" is applied to a unit ranging from 200 to a little more than 300 feet in thickness, consisting in the lower part of buff or brown sandstone and sandy shale that contains large gray to brown hard sandy concretions and in the upper part chiefly of soft sand or poorly consolidated white sandstone. In general this is also the way the Fox Hills of eastern Colorado was restricted by the Rocky Mountain Association of Petroleum Geologists in 1932.89

Because the contact of the Fox Hills sandstone and the Pierre shale is transitional in many places and because the zones of large concretions at the base of the Fox Hills were not traced in detail over the complete area from which collections were made, the fossils collected from the Fox Hills sandstone are shown in two lists. The first shows species in lots whose position is somewhat doubtful; that is, they may possibly belong to the transition zone of the Pierre shale, though the writers believe them more likely to represent Fox Hills horizons; the second shows the species in lots assigned with confidence.

The fauna contains many species that appear first in sandy rocks at various horizons in the Montana group of other areas, though such species as Baculites grandis Hall and Meek, Discoscaphites conradi (Morton), and Sphenodiscus lenticularis (Owen) always indicate a very late Cretaceous horizon wherever found. Some of the lots-for example, collection 15865-show a definite admixture of nonmarine elements, a not unusual occurrence in the Fox Hills.

\section{Fossils probably from the lower part of the Fox Hills sandstone}

Solemya bilix White____ Locality

Solemya? sp_-_. 8

Pteria nebrascana Evans and Shumard_________ 5,6

Volsella cf. V. meeki (Evans and Shumard)______ 4

Crenella elegantula Meek and Hayden_._._._._._._._.

Pholadomya n. sp

${ }^{8 s}$ Dane, C. H., and Pierce, W. G., Dawson and Laramie formations in southeastern part of Denver Basin, Colo.: Am. Assoc. Petroleum Geologists Bull., vol. 20, no. 10, pp. 1308-1328, 1936.

${ }^{89}$ Lovering, T. S., Aurand, H. A., Lavington, C. S., and Wilson, J. H., Fox Hills formation, northeastern Colorado: Am. Assoc. Petroleum Geologists Bull., vol. 16, no. 7, pp. 702-703, 1932. 